\title{
Lukasz Donaj
}

(Uniwersytet im. Adama Mickiewicza w Poznaniu)

\section{SPÓR ROSYJSKO-BIALORUSKI Z CZERWCA 2010 R. JAKO PRZYKLAD „GEOPOLITYKI RUROCIĄGÓW”}

Jeszcze do niedawna w Unii Europejskiej kwestia wspólnej polityki energetycznej była pomijana, lecz w obliczu wyczerpywania się własnych zasobów oraz coraz większego popytu na surowce ponownie znalazła się wśród tematów kluczowych. O potrzebie wspólnej polityki energetycznej przypomniał José Manuel Barosso mówiąc: „Polityka energetyczna była kluczowym obszarem polityki od początku powstania projektu europejskiego. Teraz musi ponownie stać się kwestią priorytetową".

W tym kontekście wzrasta rola gazu ziemnego. Obecnie, prowadząc politykę dywersyfikacji surowców, Unia zwiększa jego wydobycie. 22\% całego importu energii Unii to import błękitnego paliwa. Ponad 70\% wszystkich dostaw pochodzi z trzech państw: Rosji (46\%), Norwegii (27\%) oraz Algierii (20\%), co łącznie daje $93 \%$. Pozostałymi importerami gazu ziemnego dla UE są m.in. Nigeria, Egipt i państwa należące do $\mathrm{OPEC}^{2}$.

Rosja jest głównym partnerem Unii Europejskiej w dialogu energetycznym. Został on zainicjowany na szóstym szczycie UE-Rosja w Paryżu, w 2000 r. Wcześniej współpraca ta istniała na mocy Układu o Partnerstwie i Współpracy. W 2000 r. Federacja Rosyjska (FR) wyeksportowała na rynek Wspólnot 63\% sprzedawanego przez siebie gazu. Były kanclerz Niemiec, Gerhard Schröder, powiedział kiedyś: „Potrzebujemy energii, a Rosja pieniędzy; my mamy pieniądze, a Rosja źródła energii. [...] Następuje więc zbliżenie naszych interesów”3.

Celem Unii Europejskiej jest skłonienie FR do liberalizacji rynku gazu, zaś Rosja chce utrzymać monopol w tej dziedzinie. Cechą rosyjskiego eksportu błękitnego

${ }^{1}$ A. Nahrebecki, Wspólna polityka energetyczna Unii Europejskiej, Warszawa 2008, s. 8, za: A. D y l a, Rola gazu ziemnego w bezpieczeństwie energetycznym Unii Europejskiej, www. psz.pl (dostęp 13 IX 2010).

${ }^{2}$ A. D y la, op. cit.

${ }^{3}$ P. Żurawski vel Grajewski, Polityka Unii Europejskiej wobec Rosji a interesy Polski 1991-2004, Kraków 2008, s. 438, za: A. D y la, op. cit. 
paliwa jest jego przesyłanie na podstawie kontraktów długoterminowych (KDT), często z klauzulą zakazującą reeksportu (sprzedaży za granicę towarów importowanych). KDT zawierane są na co najmniej 15-20 lat i mają klauzulę take-or-pay, oznaczającą, że nabywca musi płacić określoną kwotę minimalną, także wtedy, gdy nie odbiera gazu - nie ma sankcji wobec niesolidnego dostawcy. Jak już wspomniano, nie przewiduje się odsprzedaży gazu ziemnego za granicę. Ten rodzaj umów obejmuje do chwili obecnej około $90 \%$ dostaw gazu w krajach UE ${ }^{4}$.

Nie jest zatem rzeczą dziwną, że Unia szczególnie bacznie przygląda się wszystkiemu, co wiąże się z działalnością Gazpromu, w tym także sporom $\mathrm{z}$ udziałem tego przedsiębiorstwa. W artykule niniejszym ukazana jest jedna z takich sytuacji - spór rosyjsko-białoruski z czerwca 2010 r. Analizę uzupełniają wnioski oraz prognozy na przyszłość (dotyczące nie tylko dwóch wymienionych państw, lecz także polityki energetycznej UE jako całości, a także Polski - zwłaszcza w kontekście negocjacji rządu w sprawie nowej umowy z Gazpromem).

Dla obecnej polityki zagranicznej FR jednym z większych wyzwań jest postępująca utrata strefy wpływów. Dzisiejsza Rosja praktycznie nie ma żadnych sojuszników, bo nawet Indii czy Chin za takich uznać nie sposób ${ }^{5}$. Na jej zachodnich granicach wyrasta potężny blok polityczno-ekonomiczny (UE), który powoli, acz coraz śmielej, sięga po narzędzia polityki zewnętrznej i nie zamierza respektować „,wyłączności” Rosji na przestrzeń poradziecką. Chiny stają się coraz potężniejsze, tymczasem brak porozumienia z Japonią (kwestia Kuryli' ${ }^{6}$ pozbawia Rosję potencjalnego sojusznika. Rosja cały czas nie wie, czym jest dla niej Zachód - sojusznikiem wobec innych wyzwań czy wrogiem numer jeden. Okazuje się, że pragmatyzm bez wizji polityki zagranicznej nie wystarcza?

Ten pragmatyzm - pozbawiony wizji, wyraźnej i akceptowalnej, dla innych uczestników stosunków międzynarodowych w regionie - widoczny jest wyraźnie, gdy spojrzy się na obszar Wspólnoty Niepodległych Państw (WNP). Zbliża się 20 rocznica jej powstania, jednak już od dawna znajduje się ona w głębokim kryzysie, dlatego na nikim nie robią już wrażenia kolejne deklaracje o przygotowaniach kon-

${ }^{4}$ http://eup.wse.krakow.pl/?page id=22, za: A. D y la, op. cit.

${ }^{5}$ M. K a c z mar sk i, Polityka zagraniczna Putina - chwilowy kryzys czy obnażenie braku strategii?, „Międzynarodowy Przegląd Polityczny”, www.mpp.org.pl (dostęp 12 VII 2007). Zdaniem Z. Brzezińskiego, jeżeli dojdzie do sojuszu Rosja-Chiny, to Pekin będzie odgrywać w tym tandemie rolę lidera. Chiny dysponują mądrzejszą elitą polityczną, są silniejsze w sferze gospodarczej, o wiele więcej inwestują w rozwój technologiczny niż Rosja. Chińczycy są o wiele bardziej zdyscyplinowanym narodem, łatwiej jest też robić interesy w Chinach niż w Rosji. „Szukajcie przyjaciół, nie wrogów. Rosja może wnieść znaczący wkład do cywilizacji zachodniej - uważa Zbigniew Brzeziński”, „Forum” 2006, nr 34. Zob. także: A. W i 1 k, Powrót Rosji na Ocean Światowy?, www.osw. waw.pl (dostęp 23 X 2004).

${ }^{6}$ M. K a c z mar s k i, op. cit. Szerzej na temat Wysp Kurylskich zob. Ł. D o n a j, Spór japońsko-rosyjski o Wyspy Kurylskie, [w:] Spory - konflikty zbrojne - terroryzm. Dysfunkcjonalne czynniki współczesnych stosunków międzynarodowych, red. W. Malendowski, Poznań 2006.

${ }^{7}$ M. K a c z marski, op. cit. 
cepcji reformy WNP, podpisania odkładanych ciągle porozumień wykonawczych w ramach Wspólnej Przestrzeni Gospodarczej czy perspektyw unii walutowej w ramach Euroazjatyckiej Wspólnoty Gospodarczej lub Związku Białorusi i Rosji ${ }^{8}$.

Od 2005 r. począwszy FR zrewidowała swoją politykę wobec państw WNP - najwyraźniej doszła do wniosku, że zwiększająca się obecność innych aktorów (zwłaszcza UE, USA czy Chin) na tym obszarze jest procesem, którego nie da się całkowicie zahamować, a wobec niechęci elit tych państw do uczestnictwa w inicjowanych przez władze w Moskwie form integracji i wobec widocznego wzrostu potęgi Rosji utrzymywanie pewnej fikcji nie jest już konieczne dla uzasadniania rosyjskiej mocarstwowości. Dodatkowo Rosja przekonała się (chociażby na przykładzie Ukrainy czy Białorusi), że nie można ufać deklaracjom i obietnicom, składanym przez polityków z państw WNP. Postanowiła odtąd wspierać nie osoby, lecz polityki i domagać się czynów, nie słów9

FR zastosowała nową taktykę wobec państw postrzeganych jako sojusznicy - takich jak Białoruś czy Armenia - politykę szantażu gospodarczego, domagając się w zamian za dostawy tańszej energii przekazania kontroli nad strategicznymi firmami. Pokazała w ten sposób, że nie zależy jej na pozorach budowania pozytywnych sojuszy, opartych na wspólnocie interesów i zamiast tego zamierza wymuszać ustępstwa ${ }^{10}$.

Ma to doniosłe konsekwencje - oznacza bowiem w istocie koniec ,projektu WNP", który polegał głównie na gospodarczym (i częściowo militarnym) sponsorowaniu przez Rosję przyjaznych reżimów na obszarze WNP, udzielaniu im wsparcia politycznego za cenę ich lojalności (polityka zagraniczna) i bezpieczeństwa oraz udziału w wirtualnej integracji, służącej umacnianiu prestiżu FR. Rosji nie interesują już miraże odbudowy ZSRR w jakiejś nowoczesnej formie, ale przejęcie kontroli nad kluczowymi elementami gospodarek państw WNP i związanie ich ze sobą w sposób, który pozwoli utrzymać dominację w dobie rosnącej konkurencji między innymi aktorami międzynarodowymi. Brutalność działań Rosji spowodowała raczej wzrost oporu wielu państw WNP (takich jak Gruzja, Białoruś czy Azerbejdżan), a „urynkowienie" cen importowanej z Rosji energii w istocie stanowiło krok milowy na drodze do umocnienia ich niepodległości ${ }^{11}$.

${ }^{8}$ Rocznik strategiczny 2006/2007. Przegląd sytuacji politycznej, gospodarczej $i$ wojskowej w środowisku międzynarodowym Polski, red. R. Kuźniar, Warszawa 2007, s. 191-192.

${ }^{9}$ Ibidem, s. 192. Szerzej nt. polityki zagranicznej FR zob.: A. W ło d k o w s k a, Polityka Federacji Rosyjskiej na obszarze WNP, Torun 2006; W. R a d zi w i n o w i c z, Ulubione stowo prezydenta Miedwiediewa, www.gazeta.pl (dostęp 10 VII 2010); Miedwiediew chce „,modernizować” politykę zagraniczna, „Tydzień na Wschodzie. Biuletyn analityczny OSW. Rosja, Kaukaz, Azja Centralna", 21 VII 2007, nr 25, subskrypcja OSW (www.osw.waw.pl); S. B i e l e ń, Powrót Rosji do gry wielkomocarstwowej, [w:] Rosja w okresie prezydentury Władimira Putina, red. A. Stępień-Kuczyńska, S. Bieleń, Łódź 2008.

${ }^{10}$ Rocznik strategiczny 2006/2007..., s. 192.

${ }^{11}$ Ibidem, s. 192-193. 
A laksandr Łukaszenka12 od objęcia urzędu prezydenta w $1994 \mathrm{r}$. konsekwentnie budował i umacniał autorytarny system władzy na Białorusi oraz nakazowo-rozdzielczy model gospodarczy. W rezultacie, w ciągu kilkunastu lat, ukształtował się ustrój polityczny, odporny na naciski zewnętrze i wewnętrzne protesty opozycji, określany w publikacjach prasowych mianem „ostatniej dyktatury Europy”. Wzrost presji Moskwy wobec Mińska na przełomie 2006 i 2007 r. zapoczątkował pewne zmiany wewnętrzne na Białorusi. Najbardziej znaczące procesy mają miejsce w gospodarce, co jest uwarunkowane obiektywną koniecznością obniżenia wysokich kosztów funkcjonowania niereformowanego od lat modelu ekonomicznego, pozyskania inwestorów zagranicznych i nowoczesnych technologii. Do równie istotnych zmian doszło w białoruskim obozie władzy. Miejsce konserwatywnych siłowików $w^{13}$ zajęły bardziej pragmatyczne i otwarte na świat grupy nomenklaturowe. W ten sposób reżim próbuje się dostosować do nowej sytuacji międzynarodowej ${ }^{14}$.

W 2008 r. najważniejszym czynnikiem, kształtującym sytuację na obszarze WNP był kryzys finansowy, gospodarczy, a w niektórych państwach także energetyczny. Mimo iż spadek światowych cen ropy naftowej uderzył w głównych eksporterów surowców energetycznych w regionie (w pierwszym rzędzie Kazachstan, Turkmenistan i Azerbejdżan), radziły sobie relatywnie lepiej niż inne, na ogół biedniejsze, państwa, które zostały zmuszone do poszukiwania pomocy zewnętrznej i zaczęły ją znajdować głównie w Rosji. Moskwa, choć sama przeżywała ostry kryzys, nie mogła przegapić takiej okazji wzmocnienia swoich wpływów ekonomicznych, politycznych i w dziedzinie bezpieczeństwa oraz osłabienia roli Zachodu na obszarze WNP ${ }^{15}$.

${ }^{12}$ Zob. także: Ł. D o n a j, Wizerunek Białorusi na przykładzie wybranych tytułów ukraińskiej prasy drukowanej, [w:] Białoruś. Czas zmian, red. K. Kłysiński, R. Witek, Poznań 2003.

${ }^{13} \mathrm{~K}$. Kły siń ski, A. Wi e r z bow ska-Mi a z g a, Zmiany w białoruskich elitach politycznych, gospodarce i społeczeństwie. Pozory i rzeczywistość, Warszawa 2009, s. 7. Łukaszenka pozbawił już stanowisk wielu urzędników, którzy - jego zdaniem - mogli mu zagrozić. Nie przewidział tylko, że zdymisjonowanych urzędników znających sekrety Mińska przygarnie Rosja, dając im zarobić w państwowych firmach. W razie konieczności Kreml może też sięgnąć po nich, traktując ich jako nową elitę władzy do walki z coraz bardziej nieposłusznym Moskwie prezydentem. Zob.: M. P o t o c k i, Łukaszenka kontra byli czeliści i biznesmeni. Białoruś. Skłóceni z Łukaszenka funkcjonariusze resortów siłowych dostali pracę w rosyjskim Gazpromie, „Dziennik Gazeta Prawna”, 18-20 VI 2010.

${ }^{14}$ Niewielki wpływ na sytuację wewnętrzną Białorusi mają procesy zachodzące w środowiskach opozycyjnych i w społeczeństwie. Białoruskie siły demokratyczne są pogrążone w konfliktach wewnętrznych i nie mają potencjału ani zaufania społecznego, koniecznego do inicjowania zmian w kraju. Natomiast większość białoruskiego społeczeństwa, pomimo pogarszającej się sytuacji bytowej, zachowuje dystans wobec ugrupowań opozycyjnych, skupiając się na rozwiązywaniu codziennych problemów. K. Kłysiński, A. Wi er zbowska-Miaz g a, op. cit., s. 7.

${ }^{15}$ Rocznik strategiczny 2008/2009. Przeglad sytuacji politycznej, gospodarczej $i$ wojskowej w środowisku międzynarodowym Polski, red. R. Kuźniar, Warszawa 2009, s. 219. 
Kryzys i spadający popyt zagraniczny na białoruskie produkty (w tym petrochemiczne) spowodował pod koniec 2008 r. m.in. wzrost deficytu handlowego (6,5 mld dolarów w 2008 r.) oraz zmniejszenie się rezerw walutowo-złotowych (w ostatnich dwóch miesiącach 2008 r. spadły one o jedną czwartą - do 3 mld dolarów). Konsekwencjami społecznymi były szybki wzrost zaległości w wypłatach wynagrodzeń i wymuszone przestoje w zakładach pracy oraz urlopy dla pracowników. Władze starały się jednak za wszelką cenę nie dopuścić do masowych zwolnień, mogących zdestabilizować sytuację społeczną. W ramach działań antykryzysowych o charakterze proeksportowym starano się wspierać finansowo przedsiębiorców, przyznając im czasowe ulgi podatkowe, pomoc w spłacie kredytów itp. Najpoważniejszym podjętym krokiem była skokowa dewaluacja (o około 20\%) białoruskiego rubla od 2 stycznia 2009 r. Szukano też oszczędności budżetowych ${ }^{16}$.

$\mathrm{W}$ tej sytuacji Białoruś kontynuowała politykę przyciągania zagranicznych inwestorów, a pod koniec 2008 r. zaczęła bardziej intensywnie zabiegać o znaczącą pomoc finansową. W ramach liberalizacji gospodarczej władze białoruskie m.in. wprowadziły ulgi dla inwestorów, zniosły w marcu 2008 r. tzw. „złotą akcję" (gwarantującą możliwość przejęcia przez państwo kontroli nad firmami prywatnymi). 14 kwietnia 2008 r. prezydent A. Łukaszenka podpisał dekret znoszący stopniowo (do 2011 r.) ograniczenia prywatyzacji przedsiębiorstw państwowych, co teoretycznie otwierało drogę masowej prywatyzacji, choć początkowo przepisy nie obejmowały tzw. przedsiębiorstw strategicznych. Jesienią 2008 r. Białoruś podjęła intensywne starania o kredyty, aby ratować stabilność gospodarki i finanse państwa w obliczu kryzysu. W grudniu udało się pozyskać zgodę Rosji na 2 mld dolarów kredytu, a Mińsk zabiegał o kolejne 3,5 mld. Kredyt w wysokości 2,5 mld dolarów przyznał Białorusi w styczniu 2009 r. Międzynarodowy Fundusz Walutowy. Mińsk starał się także o 5 mld dolarów od USA. Ceną, jaką musiał płacić za uzyskane (głównie z Rosji) kredyty, była realizacja rosyjskich postulatów. Wymierny efekt stanowiło podpisanie w styczniu 2009 r., po dziesięciu latach zwłoki, porozumienia o utworzeniu wspólnego z Rosją systemu obrony powietrznej (który, de facto, w dużym stopniu funkcjonował już od kilku lat) ${ }^{17}$. Szczęśli-

${ }^{16}$ A. Wi e r z b ow s k a - M i a z ga, K. Kły s i ńs ki, Białoruś walczy z kryzysem, „Tydzień na Wschodzie. Biuletyn analityczny OSW. Rosja, Kaukaz, Azja Centralna”, 7 I 2009, nr 76, za: Rocznik strategiczny 2008/2009..., s. 221.

${ }^{17}$ Praktyczne znaczenie tego porozumienia polegało na tym, że istniejący stan ulegał formalizacji i utrwaleniu, zwiększając wpływ Rosji na białoruski sektor obronny. Jeśli wierzyć przeciekom medialnym, Rosja oczekiwała wówczas za kolejne kredyty m.in. uznania niepodległości Abchazji i Osetii Południowej (z czym Mińsk ociągał się, nie chcąc psuć sobie relacji z Zachodem), a także utworzenia konsorcjum zarządzającego białoruskim sektorem naftowym, w tym rafineriami oraz - być może - zawarcia porozumienia o unii walutowej; Rocznik strategiczny 2008/2009..., s. 221-222. Szerzej nt. Abchazji i Osetii Południowej zob. m.in. Ł. D o n a j, States with Limited Recognition - The Case of Abkhazia and South Osetia (with Kosovo in the Background), "Jewro Atlantica" 2010. 
wie dla Białorusi, Rosja skoncentrowała się bardziej na forsowaniu swoich celów wobec Ukrainy i nie mogąc sobie pozwolić na konflikt na „dwóch frontach”, zgodziła się na mniejsze niż oczekiwano podwyżki cen gazu dla Białorusi w 2009 r. ${ }^{18}$

Rosnąca presja Rosji spowodowała, że prezydent A. Łukaszenka próbował się zabezpieczyć przed ewentualną dywersją polityczną, wspieraną przez Moskwę, tworząc gwarancje umocnienia oraz przedłużenia swoich rządów, jednocześnie szukał zbliżenia z Zachodem. Elementem tej gry była kontrolowana i mocno ograniczona liberalizacja polityczna na Białorusi ${ }^{19}$.

Od początku 2008 r. władze białoruskie zaczęły zwalniać z więzień i aresztów więźniów politycznych, czego domagały się UE i USA, a na początku marca UE i Białoruś porozumiały się w kwestii otwarcia w Mińsku przedstawicielstwa Komisji Europejskiej. Trend ten został na pewien czas zahamowany wiosną tego samego roku, po kolejnej fali represji wobec opozycji i niezależnych mediów. Miało to zapewne związek z konfliktami wewnętrznymi białoruskiej elity rządzącej. Tajemniczy wybuch bomby w Mińsku podczas obchodów święta niepodległości 3 lipca 2008 r. dał prezydentowi A. Łukaszence pretekst do poważnej roszady. 8 lipca został zdymisjonowany bardzo wpływowy szef Rady Bezpieczeństwa Wiktar Szejman i szef administracji prezydenta Hienadź Niewyhłas, co wzmocniło pozycję w elitach lansowanego przez prezydenta jego syna, Wiktara Łukaszenki ${ }^{20}$. To otworzyło drogę do całkowitego zwolnienia więźniów politycznych (w tym byłego rywala A. Łukaszenki w wyborach prezydenckich, Aleksandra Kazulina) w sierpniu 2008 r. 23-28 września, w zgoła odmiennej atmosferze, odbyły się wybory parlamentarne na Białorusi, uznane przez UE za ważny test intencji władz. Co prawda, tradycyjnie były one niedemokratyczne, a opozycja nie dostała się do parlamentu (co w dużej mierze było spowodowane jej niewielką aktywnością), władze pozwoliły jednak kandydatom opozycyjnym na rejestrację i prowadzenie kampanii wyborczej bez poważnych szykan. Sytuacja ta jasno pokazała Zachodowi granice możliwych ustępstw prezydenta A. Łukaszenki. Dało to UE i USA pretekst do kontynuacji dialogu z władzami białoruskimi oraz zawieszenia w październiku 2008 r. sankcji wizowych wobec wysokich urzędników

${ }^{18}$ Według informacji ujawnionych przez stronę białoruską, w ramach kontraktu podpisanego w styczniu 2009 r. Białoruś miała kupować rosyjski gaz w I kwartale 2009 r. za około 145 dolarów za 1000 m, a następnie cena miała spaść. Tymczasem w 2008 r. cena gazu wynosiła 128 dolarów i zgodnie z porozumieniami rosyjsko-białoruskimi w 2009 r. miała wzrosnąć do 200-240 dolarów; Rocznik strategiczny 2008/2009..., s. 222. Na temat stosunków rosyjsko-ukraińskich w ostatnich kilkunastu miesiącach zob. Ł. D o n a j, Ukraina 2010 - , wadliwej demokracji” ciag dalszy, „Athenaeum. Polskie Studia Politologiczne” 2010; Z. P a r a fi a n o w i c z, Drugie polowanie na ukraińskie gazociagi. Ofensywa Gazpromu. Oferta - tańszy gaz, ale za kontrolę nad przesyłem, „Dziennik Gazeta Prawna", 3-5 IX 2010.

${ }^{19}$ Rocznik strategiczny 2008/2009..., s. 222.

${ }^{20}$ Szerzej zob. A. W i e r z bow s k a - Mi a z ga, Dymisja Wiktara Szejmana - szarej eminencji Białorusi, „Tydzień na Wschodzie. Biuletyn analityczny OSW. Rosja, Kaukaz, Azja Centralna", 9 VII 2008, nr 57, za: Rocznik strategiczny 2008/2009..., s. 222. 
białoruskich $^{21}$. Białoruś pozytywnie przyjęła zaproszenie do udziału w unijnej inicjatywie Partnerstwa Wschodniego, o czym decyzja zapadła ostatecznie 20 marca $2009 \mathrm{r}^{22}$

Najpóźniej do 7 lutego 2011 r. na Białorusi powinny się odbyć wybory prezydenckie ${ }^{23}$. Wstępem do „rozgrywki” o Białoruś - w której jednym z „głównych graczy" jest Rosja - był spór z czerwca 2010 r. ${ }^{24}$

W maju 2010 r. rzecznik prasowy Gazpromu Siergiej Kuprijanow poinformował, że od początku roku strona białoruska płaci za dostawy gazu stałą cenę 150 dolarów za $1000 \mathrm{~m} 3$, mimo że - zgodnie z formułą zawartą w rosyjsko-białoruskiej umowie gazowej - cena surowca ulega zmianie co kwartał (w I kwartale 2010 r. wynosiła 169 dolarów, w drugim 184). W związku z tym w ciągu czterech miesięcy powstało zadłużenie, oceniane przez stronę rosyjską na kwotę $192 \mathrm{mln}$ dolarów. Mińsk odmówił spłaty, powołując się na praktykę regulowania należności na podstawie średniej ceny surowca, obowiązującą w 2009 r. 15 czerwca

${ }^{21}$ Rocznik strategiczny 2008/2009..., s. 222-223. Ministrowie spraw zagranicznych krajów Unii Europejskiej przedłużyli na kolejny rok sankcje wobec Białorusi, utrzymując je jednocześnie w zawieszeniu do października 2010 r. UE: Sankcje dla Białorusi wciąż w zawieszeniu, www.gazeta.pl (dostęp 14 IX 2010); Unia zawiesza sankcje wizowe wobec Białorusi, www.gazeta.pl (dostęp 14 IX 2010).

${ }^{22}$ Rocznik strategiczny 2008/2009..., s. 223. Zob. także: „,Niech omawiaja, co chcą”. Miedwiediew o Partnerstwie Wschodnim, www.gazeta.pl (dostęp 14 IX 2010).

${ }^{23}$ [Artykuł powstał w 2010 r.] 14 września 2010 r. na nadzwyczajnej sesji białoruski parlament wyznaczył datę wyborów prezydenckich na 19 grudnia 2010 r. Sądzono, iż wybory zakończą się kolejną reelekcją A. Łukaszenki, mimo eskalacji napięcia na linii Mińsk-Moskwa. Według badań (z lipca 2010 r.) niezależnego ośrodka NISEPI, poparcie dla A. Łukaszenki wynosiło ok. 45\% i miało szansę wzrastać w toku kampanii wyborczej pod wpływem dominującej w mediach propagandy państwowej. Natomiast wsparcie dla potencjalnych opozycyjnych kontrkandydatów prezydenta nie przekraczało kilku procent i nic nie wskazywało na możliwość zyskania przez nich szerszego poparcia społecznego. Wybory zostały wyznaczone na 2010 r., mimo że ostatnim możliwym konstytucyjnym terminem był 6 lutego $2011 \mathrm{r}$. Wydaje się, iż główną przyczyną tej decyzji był pogarszający się stan relacji rosyjsko-białoruskich. Spodziewano się, że narastające między stronami rozbieżności mogą doprowadzić do kolejnego kryzysu energetycznego na linii Mińsk-Moskwa na przełomie 2010 i 2011 r., co utrudniłoby kampanię wyborczą urzędującego prezydenta. Spodziewana reelekcja A. Łukaszenki w wyborach 19 grudnia miała wzmocnić jego pozycję w negocjacjach z Moskwą na temat warunków dostaw surowców energetycznych w następnym roku, co było zapewne jedną z głównych przyczyn wyznaczenia ich wcześniejszego terminu. Wybory prezydenckie na Białorusi jeszcze w tym roku, „Tydzień na Wschodzie. Biuletyn analityczny OSW. Rosja, Kaukaz, Azja Centralna", 15 IX 2010, nr 148, subskrypcja OSW (www.osw.waw.pl).

${ }^{24}$ Sytuację z czerwca 2010 r. między Rosją a Białorusią należałoby nazywać - gdyby trzymać się terminologii politologicznej i prawnej - wyłącznie sporem. W publicystyce jednak używano także terminów „konflikt”, a także „wojna”. Leksykon współczesnych międzynarodowych stosunków politycznych, red. C. Mojsiewicz, Wrocław 2000, s. 188-189 (hasło: Konflikt międzynarodowy); zob. także: Encyklopedia politologii, red. M. Żmigrodzki, t. 5: Stosunki międzynarodowe, red. T. Łoś-Nowak, Kraków 2002, s. 174-175, 342 (hasła: Konflikt oraz Spór); Pokojowe załatwianie sporów międzynarodowych, [w:] R. B i e r z a n e k, J. S y m o n i d e s, Prawo międzynarodowe publiczne, Warszawa 1995. 
prezydent Rosji przedstawił stronie białoruskiej ultimatum, w którym zażąałał spłacenia całej kwoty do 21 czerwca, pod groźbą ograniczenia dostaw gazu proporcjonalnie do wysokości zadłużenia ${ }^{25}$.

19 czerwca strony przystąpiły do rozmów, w których władze białoruskie wysunęły kwestię rosyjskiego długu za tranzyt gazu przez terytorium Białorusi na Zachód w wysokości 217 mln dolarów (później w wypowiedzi A. Łukaszenki pojawiła się kwota $260 \mathrm{mln}$ ). Choć wicepremier Rosji Igor Sieczin zanegował fakt istnienia zadłużenia, to już 21 czerwca rzecznik Gazpromu potwierdził tę informację, zarzucając władzom białoruskim blokowanie formalnych procedur regulowania opłat ${ }^{26}$. Problemem był spór o wysokość stawki tranzytowej. Gazprom płacił 1,45 dolara za przesłanie $1000 \mathrm{~m} 3$ na odcinku $100 \mathrm{~km}$, podczas gdy Białoruś domagała się kwoty 1,74 dolara. Jednocześnie odrzucona została białoruska propozycja dokonania rozliczenia w towarach. Wobec braku porozumienia 21 czerwca strona rosyjska, zgodnie z wcześniejszym ultimatum, zmniejszyła dostawy o $15 \%$, a przez kolejne dwa dni o $45 \%$, na skutek czego przesyłanie gazu zostało zredukowane o $60 \%{ }^{27}$.

W odpowiedzi 22 czerwca A. Łukaszenka wydał polecenie wstrzymania tranzytu gazu do Europy (przez Białoruś przesyłane jest około 20\% rosyjskiego eksportu tego surowca) w przypadku nieuregulowania przez Gazprom długu za tranzyt. 23 czerwca litewski operator gazowy Lietuvos Dujos poinformował

${ }^{25}$ K. Kły sińs ki, W. Kon o n oń c zu k, Rosja prowokuje konflikt gazowy z Białorusia, „Tydzień na Wschodzie. Biuletyn analityczny OSW. Rosja, Kaukaz, Azja Centralna”, 23 VI 2010, nr 22, subskrypcja OSW (www.osw.waw.pl).

${ }^{26}$ Ibidem. A. Łukaszenka grzmiał: „Problem w tym, że ja was informuję jako ministra, że na dziś Gazprom jest nam dłużny 260 mln dolarów, wliczając maj, za tranzyt gazu. Nakazałem rządowi zamknąc tranzyt przez Białoruś, póki Gazprom nie zapłaci za tranzyt. Oni nam przez te pół roku ani kopiejki nie zapłacili. Posłuchajcie, do jakiego cynizmu, jakiego absurdu można dojść, gdy ty jesteś mi winny $260 \mathrm{mln}$ dolarów, ja tobie - 190 mln dolarów, i ty za to zaczynasz mi zakręcać wentyl? Oto w czym problem. Rozumiecie, problem nie w tym, że my [...] idioci i nie wypełniamy kontraktu. To oni nie wypełniają kontraktu. My milczeliśmy, my o tym nie mówiliśmy. Oni dukali przez sekretarza prasowego, że my czegoś tam nie podpisujemy. Czego my nie podpisujemy? Co, my nie podpisujemy jakichś tam dokumentów, żeby $260 \mathrm{mln}$ dolarów dostać?" - relacja służby prasowej prezydenta Białorusi ze spotkania z ministrem spraw zagranicznych Federacji Rosyjskiej S. Ławrowem, „Narodnaja Gazieta”, 23 VI 2010; O. A n t i p i e n k o, Priezidient Aleksandr Eukaszenko: „Nie my siewodnia dałży Gazpromu - Gazprom dotżen nam”, „Komsomolskaja Prawda w Biełarusi”, 23 VI 2010.

${ }^{27}$ K. Kły s ińs ki, W. Kon on oń c zu k, op. cit.; Białoruś irytuje Rosje. Mińsk. 85 proc. dostaw gazu zagrożone, „Dziennik Gazeta Prawna”, 21 VI 2010; A. K u b 1 i k, Moskwa z Mińskiem szarpia za kurek, „Gazeta Wyborcza”, 21 VI 2010; M. P o t o c k i, Gazprom odcina Białoruś. Rosja chce zmusić Mińsk, by przystapit do unii celnej, „Dziennik Gazeta Prawna”, 22 VI 2010. W gazecie „Swabodnyje nowostii pljus” napisano: „Rano 21 czerwca prezydent FR, D. Miedwiediew, nakazał przystąpić do ograniczenia dostaw gazu dla Białorusi. «Gazprom nie może przyjmować zamiast spłaty długu pierogów, masła, sera, ani innych środków płatności» - stwierdził Dmitrij Miedwiediew”. W. L i w n i e w, Znowa ,gazowaja wojna”?, „Swabodnyje nowostii pljus”, 23-30 VI 2010. 
o 30-procentowym spadku przesyłu gazu na Litwę i do obwodu kaliningradzkiego. Jednocześnie strona białoruska uregulowała należność za dostawy surowca z maja, płacąc 184 dolarów za $1000 \mathrm{~m}^{3}$, zgodnie ze stawką obowiązującą w II kwartale 2010 r. Natomiast spłatę pozostałego zadłużenia (192 mln dolarów) Mińsk zadeklarował do 5 lipca. Strona rosyjska odrzuciła jednak wszelkie propozycje i domagała się natychmiastowego zwrotu zadłużenia, co podnosiło napięcie pomiędzy stronami sporu ${ }^{28}$. Zdaniem ekspertów OSW, w tym sporze chodziło o osiągnięcie co najmniej trzech celów. Po pierwsze, doraźnym celem Kremla było skłonienie Białorusi do ratyfikacji Kodeksu Celnego Unii Celnej. Białoruś uzależniała swój udział w tej strukturze od zniesienia ceł na ropę naftową i produkty naftowe. Projekt miał/ma dla Rosji duże znaczenie polityczne i gospodarcze, a jego blokowanie przez Mińsk mogło doprowadzić do prestiżowej porażki forsowanej przez Rosję struktury (zainicjowanie jej działalności miało nastąpić 5 lipca w Astanie $)^{29}$. Po drugie, Moskwa, zdając sobie sprawę z pogarszającej się sytuacji finansowej Białorusi, sygnalizowała, że oczekuje przestrzegania przez stronę białoruską kontraktu gazowego oraz nie zamierza przywracać wcześniejszych subsydiów gospodarczych (dostaw tańszego gazu i bezcłowej ropy). Działania Rosji miały tym samym na celu skłonienie Mińska do sprzedaży koncernom rosyjskim strategicznych aktywów w gospodarce białoruskiej - w tym przede wszystkim dwóch rafinerii oraz pakietu kontrolnego w przedsiębiorstwie Biełtransgaz (50\% Gazprom nabył w latach 2007-2010) ${ }^{30}$. Po trzecie, Rosja po raz kolejny usiłowa-

${ }^{28}$ K. Kły siński, W. Kon on ońc zuk, op. cit.; M. Dus zczy k, Zagrożone dostawy gazu, „Dziennik Gazeta Prawna”, 23 VI 2010; i d e m, Polacy będa monitorować tranzyt gazu przez Białoruś. Surowce. Zaostrza się spór Kremla z Mińskiem, „Dziennik Gazeta Prawna”, 24 VI 2010; Białoruś ostrzega: Teraz zmniejszenie tranzytu do Europy?, www.gazeta.pl (dostęp 21 VI 2010); Stop tranzytowi gazu przez Białoruś. Łukaszenka zakręca kurek, www.gazeta.pl (dostęp 22 VI 2010); Białoruś grozi Rosji przerwaniem tranzytu gazu i ropy, www.gazeta.pl (dostęp 25 VI 2010). A. Miller stwierdził: „Białoruś stara się stworzyć pułapkę ofsajdową w rozmowach o gazie. To znaczy, że będzie można im strzelić gola. Komentarz redakcji brzmiał: „Gazowy futbol” z białoruskimi partnerami - gra niebezpieczna. Żeby tylko klienci z Europy nie zdyskwalifikowali obu drużyn do końca... gazu”. S. R i e p o w, A. F u f y r i n, Zakony szaurmy, „Argumenty i Fakty w Biełarusi”, 23 VI 2010.

${ }^{29}$ K. Kł y s i ń s k i, W. K o n o n o ń c z u k, op. cit. Zdaniem A. Rahra, A. Łukaszenko znalazł się w bardzo trudnej sytuacji. Poczynając od 2007 r., kiedy miał miejsce pierwszy poważny konflikt z Rosją (wtedy dotyczył ropy naftowej), próbował zbalansować swoją politykę i wykorzystać pomoc Unii Europejskiej, a także zachodniego biznesu, by przesunąć Rosję na drugi plan odnośnie do tego, co dotyczyło prywatyzacji na Białorusi. To się jednak nie udało. Ekspert ten stwierdził ponadto: „Na Białoruś naciskają, by wstąpiła do Unii Celnej na warunkach Rosji”. Zob.: Łukaszenko gatow atstupat, rozmowa z Aleksandrem Rahrem - ekspertem Niemieckiego Towarzystwa Polityki Zagranicznej, przeprowadzona przez W. Dorochowa, „Swabodnyje nowostii pljus”, 23-30.06.2010; Kommientarij, „Komsomolskaja Prawda w Biełarusi”, 23 VI 2010.

${ }^{30} \mathrm{~K}$. Kły siński, W. Kon o nońc zuk, op. cit. Zob. szerzej: K. Kły s iński, Rosja i Białoruś ustalaja ksztalt wzajemnych relacji w sferze gospodarczej, „Tydzień na Wschodzie. Biuletyn analityczny OSW. Rosja, Kaukaz, Azja Centralna”, 16 XII 2009, nr 43, subskrypcja OSW 
ła wykazać niewiarygodność Białorusi jako państwa tranzytowego oraz partnera handlowego i jeszcze bardziej pogorszyć jej wizerunek na Zachodzie. Dlatego też wyraźnie starała się umiędzynarodowić ten konflikt, szczególnie w relacjach z UE. Nie można było również wykluczyć, że w ten sposób zamierzano udowodnić europejskim odbiorcom gazu konieczność budowy gazociągów Nord Stream i South Stream, omijających państwa tranzytowe ${ }^{31}$.

(www.osw.waw.pl); i d e m, Rosja-Białoruś: decydująca faza rozgrywki o aktywa w biatoruskiej energetyce?, „Tydzień na Wschodzie. Biuletyn analityczny OSW. Rosja, Kaukaz, Azja Centralna”, 6 I 2010, nr 1, subskrypcja OSW (www.osw.waw.pl); Białoruś poszukuje źródet finansowania, „Tydzień na Wschodzie. Biuletyn analityczny OSW. Rosja, Kaukaz, Azja Centralna”, 31 III 2010, nr 13, subskrypcja OSW (www.osw.waw.pl); Białoruś: Przygotowania do prywatyzacji strategicznych przedsiębiorstw, „Tydzień na Wschodzie. Biuletyn analityczny OSW. Rosja, Kaukaz, Azja Centralna”, 30 VI 2010, nr 23, subskrypcja OSW (www.osw.waw.pl); Białoruś: brak opłacalnej alternatywy dla rosyjskiej ropy, „Tydzień na Wschodzie. Biuletyn analityczny OSW. Rosja, Kaukaz, Azja Centralna", 21 VII 2010, nr 25, subskrypcja OSW (www.osw.waw.pl); Mińsk wyemituje obligacje za 2 mld dolarów. Białoruś. Łukaszenka łata dziurę budżetowa, „Dziennik Gazeta Prawna”, 13 VII 2010; P. A r a b o w, Protiwo-gaz. Alieksandr Łukaszenko zakrutit wientil na tranzitnom trubie w Jewropu, „Izwiestija”, 23 VI 2010; Kako tranzit saroststoimosti gaza na ekonomikie Bielorusi?, „Swabodnyje nowostii pljus”, 23-30 VI 2010, www.naviny.bu.

${ }^{31}$ K. Kł y s iń s k i, W. K o n o n o ń c z u k, op. cit. Zob. także: „Jesteśmy nieustannie szantażowani”. Łukaszenka skarży się studentom, www.gazeta.pl (dostęp 8 VII 2010). Rosyjskie błękitne paliwo dociera do Europy trzema podstawowymi trasami lądowymi. Najważniejszy system magistrali eksportowych biegnie z Federacji Rosyjskiej przez Ukrainę (obsługuje on ok. 90\% rosyjskiego eksportu gazu do Europy) i Słowację - do państw zachodniej części kontynentu. Druga trasa, Jamał-Europa Zachodnia (gazociąg jamalski), biegnie przez Białoruś do Polski i dalej do Niemiec. Trzeci szlak prowadzi na Bałkany i do Turcji (w celu odciążenia tej trasy i zmniejszenia zależności od krajów tranzytowych Gazprom wspólnie z włoską firmą ENI zbudował gazociąg Błękitny Potok, którego odcinek biegnie pod Morzem Czarnym i łączy bezpośrednio południową Rosję z Turcją). Nord Stream (NS) i South Stream (SS) - bliźniacze elementy strategii rosyjskiego monopolisty gazowego - mają bezpośrednimi połączeniami uzupełnić istniejącą infrastrukturę przesyłania rosyjskiego surowca na europejski rynek zbytu przez Ukrainę i Białoruś. Nowe magistrale mają otoczyć Europę Środkową i Wschodnią od północy, przez Bałtyk (NS) i od południa, przez Morze Czarne (SS) i umożliwić transport gazu z Rosji wprost do odbiorców w Europie, z pominięciem (lub ograniczeniem roli) obecnych państw tranzytowych. Nord Stream - starszy z dwóch projektów - powstał w 1997 r. jako projekt trasy bezpośredniego przesyłania gazu z Rosji do północnych Niemiec i Europy Zachodniej via Bałtyk. Nowy gazociąg miał nie tylko dywersyfikować szlaki eksportu rosyjskiego gazu na wypadek problemów z państwami tranzytowymi, lecz także otworzyć Gazpromowi drogę na nowe rynki w Europie. Wydobycie na Morzu Północnym spada, a dzisiejsi producenci i netto-eksporterzy błękitnego paliwa - Dania, Holandia, Wielka Brytania - stają się importerami gazu. Zredukowany projekt (zrezygnowano m.in. z budowy odgałęzienia do Wielkiej Brytanii) przewiduje budowę dwunitkowego gazociągu o łącznej przepustowości $55 \mathrm{mld}^{3}$ rocznie (po 27,5 $\mathrm{mld}^{3}$ ). Termin uruchomienia pierwszej nitki przypadał na rok 2011, termin uruchomienia drugiej - na 2012. Znacznie mniej zaawansowany South Stream pojawił się w 2007 r. jako reakcja na unijny projekt Nabucco (alternatywny gazociąg omijający Rosję, który ma zdywersyfikować źródła dostaw gazu do Europy i dostarczać na rynek unijny surowiec z Azji Centralnej i Bliskiego Wschodu). Gazociąg ten o łącznej przepustowości $63 \mathrm{mld} \mathrm{m}^{3}$ rocznie miałby połączyć Rosję przez Morze Czarne i Bułgarię z Europą Środkową (nitka północna przez Serbię, Słowenię - do Austrii) i z Europą Po- 
2 lipca rosyjski koncern Gazprom i białoruska kompania gazowa Biełtransgaz uzgodnili podniesienie stawki tranzytowej za przesyłanie rosyjskiego gazu przez terytorium Białorusi oraz wzrost hurtowej ceny surowca dla odbiorców w tym kraju. Formalnie kończy to dwustronny spór gazowy, który w czerwcu doprowadził do trzydniowego ograniczenia przez Rosję dostaw gazu na Białoruś. Porozumienie ma jednak charakter tymczasowy, gdyż najważniejsze kwestie sporne w dwustronnych relacjach, zarówno gazowych, jak i naftowych, wciąż pozostają nieuregulowane ${ }^{32}$.

Strony zgodziły się na wniesienie zmian do kontraktu o dostawach gazu na Białoruś w latach 2007-2011, zgodnie z którymi w 2010 r. Gazprom płacił 1,88 dolara za przesył $1000 \mathrm{~m} 3$ surowca na odcinku $100 \mathrm{~km}$. Oznacza to, że rosyjski monopolista zgodził się zapłacić 32 mln dolarów długu za tranzyt w 2010 r., co było jednym z żądań Mińska. Uzgodniono również, że Biełtransgaz podniesie hurtową cenę gazu dla odbiorców białoruskich oraz w latach 2011-2012 ograniczy do minimum część zysku przekazywaną do Funduszu Innowacyjnego białoruskiego Ministerstwa Energetyki, co wcześniej kwestionował Gazprom (zmniejszało to bowiem dochody przedsiębiorstwa) ${ }^{33}$.

Białoruś uległa Rosji w kwestii wprowadzenia unii celnej. 5 lipca w Astanie prezydenci Rosji, Kazachstanu i Białorusi podpisali oświadczenie o wejściu w życie wspólnego Kodeksu Celnego. Formalnie oznaczało to powstanie unii celnej (UC) między tymi państwami, jednak w rzeczywistości będzie to jedynie jej namiastka. Mimo swych ograniczeń UC może okazać się korzystna dla współpracy ekonomicznej tych państw. Negatywną konsekwencją jej powołania jest jednak wydłużenie procesu akcesyjnego Rosji do Światowej Organizacji Handlu ${ }^{34}$.

Zgodnie z przyjętymi dokumentami, od lipca 2010 r. Rosja, Białoruś i Kazachstan formalnie utworzyły wspólną przestrzeń celną (zasady jej funkcjonowania są bardzo zbliżone do tych dotychczas obowiązujących na terytorium Rosji), na obszarze której większa część wymiany towarowej podlegać ma zasadom wolnego handlu. Integrujące się kraje wprowadziły jednolitą (z wyjątkami) taryfę

łudniową (nitka południowa do Grecji i Włoch). Projekt nie przewiduje wejścia Gazpromu na nowe rynki, a jedynie ewentualne zwiększenie dostaw rosyjskiego gazu dla stałych jego odbiorców w tych państwach. Według ostatnich planów, gazociąg miałby być uruchomiony w 2015 r. A. Ło s k o t, Bezpieczeństwo dostaw rosyjskiego gazu do UE - kwestia połaczeń infrastrukturalnych, Warszawa, luty 2005, www.osw.waw.pl (dostęp 12 XII 2008); Nord Stream czyli Gazociag Pótnocny - informacje, http://weglowodory.pl (dostęp 16 IX 2010); E. P a s z y c, Nord Stream i South Stream nie rozwią̇a problemów Gazpromu, „Komentarze OSW”, 28 I 2010, nr 35.

32 Tymczasowe uregulowanie rosyjsko-białoruskiego sporu gazowego, „Tydzień na Wschodzie. Biuletyn analityczny OSW. Rosja, Kaukaz, Azja Centralna”, 7 VII 2010, nr 24, subskrypcja OSW (www.osw.waw.pl).

${ }^{33}$ Ibidem.

${ }^{34}$ I. W i śn i e w s k a, Unia celna - polityczny projekt Rosji, „Tydzień na Wschodzie. Biuletyn analityczny OSW. Rosja, Kaukaz, Azja Centralna”, 7 VII 2010, nr 24, subskrypcja OSW (www. osw.waw.pl). 
celną na import towarów oraz wspólny Kodeks Celny, który reguluje procedury stosowane przy imporcie i eksporcie towarów na obszarze UC. Strony przygotowują ponadto harmonizację standardów technicznych, sanitarnych i fitosanitarnych (standardy te najprawdopodobniej będą zgodne z obowiązującymi w Unii Europejskiej, bowiem w czerwcu 2010 r. Rosja zharmonizowała swoje standardy $\mathrm{z}$ unijnymi) ${ }^{35}$.

Powołana przez Rosję, Kazachstan i Białoruś UC ma jednak bardzo wiele ograniczeń. Ze wspólnej taryfy celnej wyłączono ponad 400 wrażliwych dla stron towarów, w tym tak kluczowe jak samochody osobowe (Kazachstan i Białoruś utrzymają cła niższe od rosyjskich). Ze względu na te różnice, na wewnętrznych granicach zostanie zachowana kontrola celna towarów wwożonych z państw trzecich. Strony nie przyjęły wielu szczegółowych aktów prawnych, regulujących ich politykę celną. Istotnym wyłączeniem spod reżimu wolnego handlu w ramach UC są cła eksportowe na część (nie przeznaczoną na potrzeby wewnętrzne) rosyjskiej ropy i produktów naftowych, dostarczanych na Białoruś. Należy się spodziewać, że w handlu wewnętrznym, w ramach UC, nadal będą obowiązywać inne bariery, głównie środki pozataryfowe (m.in. kwoty czy subwencje). Zniesienie utrzymanych ograniczeń w funkcjonowaniu UC ma nastąpić, zgodnie z rosyjskimi deklaracjami, do 1 stycznia 2012 r., tj. do chwili utworzenia wspólnej przestrzeni gospodarczej na obszarze tych trzech państw. Biorąc pod uwagę utrzymujące się różnice interesów między partnerami, wydaje się to jednak mało prawdopodobne ${ }^{36}$.

Ograniczony wymiar UC (podyktowany przede wszystkim rosyjskimi interesami) oraz dotychczasowe doświadczenia integracji gospodarczej w regionie (m.in. nierespektowanie zawartych porozumień) wskazują na głównie polityczne motywy lobbowanego przez Moskwę porozumienia. Biorąc pod uwagę niezmienność rosyjskich interesów, związanych m.in. z ochroną własnego rynku przed towarami z Białorusi i Kazachstanu, można spodziewać się problemów z realizacją reguł UC. Rosja, wymuszając na Kazachstanie i Białorusi zgodę na powołanie UC, chciała zatem zademonstrować swoją dominującą rolę w regionie oraz swą atrakcyjność (soft power) nie tylko w sferze politycznej i bezpieczeństwa, lecz także w kwestiach gospodarczych ${ }^{37}$. Aby zachować chociaż częściowe preferen-

35 Ibidem.

${ }^{36}$ Ibidem. Zob. także: Wschodnia unia celna funkcjonuje tylko na papierze, rozmowa z Iwoną Wiśniewską z Zespołu Rosyjskiego Ośrodka Studiów Wschodnich im. Marka Karpia, przeprowadzona przez P. Bąk, „Dziennik Gazeta Prawna”, 6 IX 2010; N. O 1 s z a n e c k a, Unia Celna Rosji, Białorusi i Kazachstanu: główne cele, główni wygrani, www.psz.pl (dostęp 16.09.2010).

${ }^{37}$ I. W i śn i e w s k a, op. cit. Zob. także: Polityczna unia celna bez Białorusi?, „Tydzień na Wschodzie. Biuletyn analityczny OSW. Rosja, Kaukaz, Azja Centralna”, 9 VI 2010, nr 20, subskrypcja OSW (www.osw.waw.pl); Wirtualna unia celna na realnym terytorium, „Tydzień na Wschodzie. Biuletyn analityczny OSW. Rosja, Kaukaz, Azja Centralna”, 26 V 2010, nr 19, subskrypcja OSW (www.osw.waw.pl); Łukaszenka zgodził się na unię celna z Rosją. Białoruś. Efekt gazowej wojny, 
cje w relacjach gospodarczych i energetycznych z Rosją, Mińsk musiał zgodzić się na utworzenie UC na warunkach rosyjskich. Przystąpienie Kazachstanu do UC można natomiast określić jako polityczny gest Astany wobec Rosji (co jest szczególnie ważne w kontekście obecnej niestabilnej sytuacji w Kirgistanie) ${ }^{38}$.

Białoruś podejmuje działania, mające na celu zmniejszenie jej zależności gospodarczej od FR. 24 sierpnia 2010 r. opublikowano tekst Strategii rozwoju potencjału energetycznego Republiki Białoruś, uchwalonej przez Radę Ministrów na początku sierpnia. Dokument stanowi kompleksową strategię modernizacji i rozwoju białoruskiego sektora energetycznego. Z powodu nasilających się problemów w relacjach z Rosją - głównym dostawcą surowców energetycznych - kwestia dywersyfikacji źródeł nośników energii jest kluczowym elementem przyjętej strategii. Autorzy opracowania założyli, że wydobycie ropy w Wenezueli oraz (uruchamiane w 2010 r.) w Iranie pozwoli na dostawy drogą morską około 10 $\mathrm{mln}$ ton ropy rocznie ${ }^{39}$. Z kolei w ,sferze gazowej” władze białoruskie planują uruchomienie dostaw gazu LNG poprzez terminale w Polsce i na Litwie ${ }^{40}$, które docelowo powinny osiągnąć poziom $10 \mathrm{mld} \mathrm{m}^{3}$. Realizacja tych projektów w obu przypadkach zmniejszyłaby o około 50\% roczne dostawy z Rosji. Dodatkowo założono w ciągu najbliższych 10 lat zwiększenie udziału własnych nośników energii (m.in. torf, odpadki drzewne) w bilansie energetycznym kraju z obecnych

„Dziennik Gazeta Prawna”, 5 VII 2010; I. K ryłow i c z, Biełarus rabotajet nad dokumentami, „Biełarusy i rynok”, 21 VI 2010; T. M a n i e n o k, Otstajuszczij nie taropitsa, „Komsomolskaja Prawda w Biełarusi”, 23 VI 2010.

${ }^{38}$ I. W i ś n i e w s k a, op. cit. Szerzej nt. aktualnej sytuacji w Kirgistanie zob. m.in.: Moskwa stawia na Atmazbeka Atambajewa?, „Tydzień na Wschodzie. Biuletyn analityczny OSW. Rosja, Kaukaz, Azja Centralna”, 8 IX 2010, nr 29, subskrypcja OSW (www.osw.waw.pl); Kirgistan: Narasta opór wobec wprowadzenia doradców policyjnych OBWE, „Tydzień na Wschodzie. Biuletyn analityczny OSW. Rosja, Kaukaz, Azja Centralna", 4 VIII 2010, nr 26, subskrypcja OSW (www. osw.waw.pl); Kirgistan - zamieszki i demonstracje, „Tydzień na Wschodzie. Biuletyn analityczny OSW. Rosja, Kaukaz, Azja Centralna”, 18 VIII 2010, nr 27, subskrypcja OSW (www.osw.waw.pl); Kirgistan: wolne miasto Osz?, „Tydzień na Wschodzie. Biuletyn analityczny OSW. Rosja, Kaukaz, Azja Centralna", 1 IX 2010, nr 28, subskrypcja OSW (www.osw.waw.pl); Krwawe starcia w Kirgistanie - Komisja Europejska wysyła eksperta, www.gazeta.pl (dostęp 16.09.2010); Kirgistan: po krwawych zamieszkach wyjątkowo spokojne referendum, www.gazeta.pl (dostęp 16.09.2010); Kirgistan ma nowa prezydent. Pierwsza kobieta na tym stanowisku, www.tvn24.pl (dostęp 16.09.2010); Gaz, granaty, strzały. Kirgistan znów niespokojny. „Przygotowywany jest zbrojny zamach stanu”, www.tvn24.pl (dostęp 16.09.2010); Kirgistan proponuje Rosji układ na pół wieku. Rosyjskie wojska zostana, a Moskwa da broń, www.tvn24.pl (dostęp 16.09.2010).

39 Strategia energetyczna Białorusi, ,Tydzień na Wschodzie. Biuletyn analityczny OSW. Rosja, Kaukaz, Azja Centralna”, 1 IX 2010, nr 28, subskrypcja OSW (www.osw.waw.pl). Szerzej nt. wenezuelskiej ropy zob.: Kijów pomoże Białorusi uniezależnić się od Rosji. Białoruś. Ropa z Wenezueli przez Ukrainę, „Dziennik Gazeta Prawna”, 14 VII 2010; O. S z e s t i a k o w a, Pierwuju partiju wenesuelskoj niefti Białarus uże prodała, „Komsomolskaja Prawda w Biełarusi”, 23 VI 2010.

${ }^{40}$ Strategia energetyczna Białorusi... Szerzej zob.: M. P ot ocki, N. Dżikija, Wilno i Mińsk uwalniaja się od Gazpromu. Energetyka. Powstanie kolejny terminal skroplonego gazu nad Battykiem, „Dziennik Gazeta Prawna”, 27 VII 2010. 
20 do ponad 30\%. Ponadto zapisano szereg inwestycji modernizujących sektor energetyczny Białorusi, których łączny koszt do 2020 r. miałby wynieść około 46 mld dolarów. Przyjęta strategia trafnie określa główne słabości białoruskiej energetyki, jakimi są przede wszystkim zależność od rosyjskich dostaw oraz przestarzała infrastruktura. Jednak postawione w niej cele przerastają realne możliwości Białorusi, tym bardziej, że na razie brak dowodów opłacalności ambitnych projektów alternatywnych dostaw ${ }^{41}$.

Jak wspomniano, porozumienie między Białorusią a Rosją z 2 lipca ma charakter tymczasowy i nie rozwiązuje istoty sporu. Do kolejnej, znacznie poważniejszej, konfrontacji na linii Mińsk-Moskwa dojdzie najprawdopodobniej pod koniec roku, kiedy strony przystąpią do ustalania warunków współpracy gazowej i naftowej na 2011 r. (dotyczyć to będzie m.in. wysokości stawki tranzytowej za przesyłanie gazu i kwestie cła na ropę rosyjską) ${ }^{42}$.

Obok wojny gazowej między Rosją a Białorusią trwała też wojna informacyjna. Początkowo wzajemne oskarżenia padały z ust przywódców obu krajów. Potem do „wojny informacyjnej” wciągnięto dziennikarzy. Rosyjska stacja telewizyjna NTV wyemitowała kilkuczęściowy film pt. Ojciec Chrzestny, w którym pokazano A. Łukaszenkę jako dyktatora czerpiącego korzyści z przestępczej działalności $^{43}$. W filmie prezydent Białorusi został zestawiony z A. Hitlerem. Pojawiło się

${ }^{41}$ Strategia energetyczna Białorusi... Jednym z pomysłów A. Łukaszenki na uzupełnienie budżetu państwa, uszczuplonego wskutek m.in. sporu i ustaleń z FR było wyemitowanie euroobligacji - do końca 2010 r. Białoruś miała zamiar wyemitować pięcioletnie euroobligacje o wartości 1 mld dolarów. Pozostała pula papierów wartościowych miała trafić na europejski i rosyjski rynek do końca 2011 r. Jak szacują analitycy, emisja obligacji kosztowała Białoruś dwa razy więcej niż pożyczka udzielona przez MFW czy Bank Światowy. Decydując się na droższy sposób wsparcia budżetu, A. Łukaszenka starał się ominąć warunki stawiane przez potencjalnych koedytorów (np. pomoc finansowa MFW wiąże się z koniecznością przeprowadzenia reform, które mogą osłabić kontrolę władz nad gospodarką oraz wywołać niezadowolenie społeczne). Eksperci zwracają uwagę na fakt, że pozycja Białorusi na arenie międzynarodowej nie jest zbyt mocna, stąd trudno szacować, czy emisja obligacji była dla niej opłacalna. Mińsk wyemituje obligacje za 2 mld dolarów...

${ }^{42} \mathrm{~K}$. Kły s ińs ki, W. K o n o n oń c z u k, op. cit. 3 września 2010 wiceszef zarządu Gazpromu, Andriej Krugłow, zapowiedział, że w następnym roku cena gazu dla Białorusi, Mołdawii i Armenii zostanie podniesiona do poziomu europejskiego. Oznaczałoby to ostatni etap odchodzenia przez rosyjski koncern od ulg cenowych dla niektórych państw obszaru WNP. Cena gazu dla Mołdawii osiągnęła wówczas poziom porównywalny z odbiorcami europejskimi i wyniosła 260 dolarów za $1000 \mathrm{~m}^{3}$. Stąd zapowiedź wiceszefa Gazpromu miała znaczenie głównie dla Białorusi i Armenii, kupujących rosyjski gaz po cenach ulgowych, 194 i 180 dolarów. Zarówno Erewan, jak i Mińsk, w związku z coraz trudniejszą sytuacją budżetową, dążyły do utrzymania ulgi. Podpisany 31 grudnia 2006 r. rosyjsko-białoruski kontrakt gazowy przewidywał przejście od 2011 r. na tzw. cenę europejską (dla odbiorców w Europie, z wyłączeniem obszaru WNP i państw bałtyckich, wynoszącą, według Gazpromu, w I kwartale 2010 r. ok. 285 dolarów). Gazprom zapowiada podwyżkę cen...

${ }^{43}$ Wojna informacyjna Rosji i Białorusi w TV, www.gazeta.pl (dostęp 19.07.2010). Zob. także: Rosyjska kampania informacyjna przeciwko Lukaszence, kam, „Tydzień na Wschodzie. Biuletyn analityczny OSW. Rosja, Kaukaz, Azja Centralna”, 21 VII 2010, nr 25, subskrypcja OSW (www. osw.waw.pl). Ośrodek Studiów Wschodnich im. Marka Karpia (OSW), przywoływany kilkukrotnie 
też oskarżenie, że jego podwładni stali za zabójstwami politycznymi na Białorusi. Dokument opisywał również ze szczegółami prywatne życie białoruskiego lidera. Twórcy filmu informowali, że podczas robienia zdjęć ekipa NTV została zatrzymana, a materiał skonfiskowano, ale ,przyjaciele” z białoruskiego KGB wydostali kasety z filmem. Druga część opisuje powiązania A. Łukaszenki z byłym prezydentem Kirgistanu Kurmanbekiem Bakijewem, któremu udzielił azylu, gdy ten stracił władzę w wyniku przewrotu. Autorzy filmu analizują nielegalne, ich zdaniem, źródła dochodów Bakijewa, porównując je z majątkiem A. Łukaszenki. Kolejnym oskarżeniem jest opisywana w filmie współpraca białoruskiego lidera ze ściganym przez Kreml rosyjskim oligarchą Borysem Bieriezowskim. W negatywnym świetle przedstawiana jest także rzekoma przyjaźń białoruskiego prezydenta z Micheilem Saakaszwilim, prezydentem Gruzji ${ }^{44}$.Trzeci odcinek filmu był poświęcony korupcji w otoczeniu prezydenta oraz pikantnym szczegółom z jego życia osobistego. Zdaniem twórców filmu, białoruska gospodarka jest w całości kontrolowana przez rodzinę A. Łukaszenki i jego pogrążone w korupcji otoczenie. Majątek prezydenta NTV szacuje na 8 do 10 mld dolarów. W filmie występuje m.in. Wiaczesław Dudkin, były szef wydziału ds. walki z korupcją MSW, który prowadził dochodzenia dotyczące korupcji wśród najwyższych rangą urzędników. W. Dudkin opowiada o gigantycznym przemycie towarów z Zachodu do Rosji, kontrolowanym przez urzędników białoruskich. Wśród nich wymienił byłego szefa KGB Sciapana Sucharenkę, szefa Komitetu Kontroli Państwowej Zianona Łomacia i byłego szefa administracji prezydenta Wiktara Szejmana. W. Dudkin twierdzi, że to starszy syn A. Łukaszenki Wiktar, który nadzorując wszystkie resorty siłowe zablokował dochodzenie w tej sprawie i doprowadził do aresztowań wśród członków grupy śledczej MSW. W ten sposób miał chronić swoje interesy. „Ja nigdy nie pracowałem dla korporacji «Łukaszenka i jego synowie»" - zapewnia mieszkający w jednym z krajów UE W. Dudkin. Według NTV, jeszcze w czasie służby w wojsku lekarze wykryli u A. Łukaszenki chorobę psychiczną. Diagnozę dziesięć lat temu miał potwierdzić mohylewski lekarz psychiatra Leonid Szczegelski, który pod przybranym nazwiskiem ukrywa się dziś na Zachodzie ${ }^{45}$.

\footnotetext{
w niniejszym artykule, powstał w 1990 r. Jest instytucją ekspercką, zajmującą się analizą sytuacji politycznej, gospodarczej i społecznej w państwach sąsiadujących z Polską, na obszarze Europy Środkowej, Europy Wschodniej, Półwyspu Bałkańskiego, Kaukazu Południowego, Azji Centralnej i Niemiec. Szczególnie aktywnie włącza się w dyskusję dotyczącą polityki wschodniej Unii Europejskiej, wyzwań związanych z bezpieczeństwem energetycznym oraz procesów transformacji politycznej i społeczno-gospodarczej sąsiadów Polski. Celem Ośrodka jest stymulowanie debaty eksperckiej oraz wsparcie informacyjne i analityczne polskich decydentów. Pracuje w nim ok. 50 analityków, jest w całości finansowany z budżetu państwa; www.osw.waw.pl (dostęp 16.09.2010).

${ }^{44}$ Łukaszenka jak Hitler: rosyjska telewizja pokaże film krytyczny wobec dyktatora Białorusi, www.gazeta.pl (dostęp 19.07.2010). Zob. także: „, Rosja chce dusić Łukaszenkę do końca”. Medialna wojna między Rosją i Białorusia, www.gazeta.pl (dostęp 19.07.2010).

${ }^{45}$ A. P o c z o b u t, Bić Łukaszenke,, „Gazeta Wyborcza”, 17 VIII 2010.
} 
Emisję trzeciej części poprzedziła ostra wymiana zdań pomiędzy rosyjskim prezydentem D. Miedwiediewem i A. Łukaszenką. Pierwszy z nich powiedział rosyjskim dziennikarzom, że podczas jednego ze spotkań przywódców WNP A. Łukaszenka obiecał publicznie uznanie Osetii Południowej i Abchazji, ale tej obietnicy nie dotrzymał. A. Łukaszenka zdementował to, zarzucając D. Miedwiediewowi wyrwanie jego wypowiedzi z kontekstu. Odpowiedź Kremla była natychmiastowa: „Możemy ujawnić stenogramy z wypowiedziami prezydenta Białorusi na temat uznania Osetii Południowej i Abchazji. Jesteśmy też gotowi ujawnić i inne wypowiedzi Łukaszenki, które będą ciekawe, zarówno opinii publicznej w Białorusi, jak i międzynarodowej społeczności” - powiedział doradca prezydenta Rosji Siergiej Prichodźko ${ }^{46}$.

W odpowiedzi na takie ataki białoruska telewizja państwowa wyemitowała m.in. wywiad z prezydentem Gruzji M. Saakaszwilim, w którym oskarżał on Rosję o rozpętanie wojny na Kaukazie ${ }^{47}$. W podobnym tonie wypowiadały się media drukowane, dołączając do oskarżeń nutę „historyczno-nostalgiczną”. Gazety białoruskie (ich rynek nie jest zbyt obszerny) obfitowały w listy czytelników, którzy zapewniali o poparciu działań prezydenta: „Dziś jestem dumny z Białorusi! Codziennie, w każdej godzinie, patrząc jakimi perfidnymi metodami próbuje się ją zmusić do klęczenia, chce się krzyknąć: «To się nie uda, panowie!». Wierzę w to, że do mych poglądów przyłączą się tysiące Rosjan, zawsze gotowych podać pomocną dłoń białoruskiemu bratu i przyjacielowi" (Walierij Karandzej, Władywostok, ul. Pieczierskaja $8 / 54)^{48}$.

Pisano także m.in.:

- „22 czerwca Gazprom wypowiedział Białorusi wojnę. Gazową. Jakim brakiem wyczucia trzeba się wykazywać, żeby zapomnieć, co znaczy ta bolesna data w historycznej pamięci Białorusinów i Rosjan? Czy naprawdę pieniądze nie śmierdzą?" 49

- S. Musienko, kierownik centrum analitycznego Ecoom: „Ultimatum Gazpromu w kontekście pamiętnego dla nas wszystkich dnia - 22 czerwca - odbieram jako osobistą obrazę. Tak nie można się zachowywać. Dla przykładu, prezydent Niemiec tylko pozwolił sobie na niewłaściwe wypowiedzi o działaniach wojennych w Afganistanie i był zmuszony złożyć dymisje" 50 .

- 15 czerwca rosyjski prezydent Dmitrij Miedwiediew nakazał szefowi Gazpromu Alieksiejowi Millerowi dać Białorusi ,5-dniowy termin” w celu uregulowania długu za gaz (pięciodniowy z racji tego, że kraje te są dla siebie kluczowymi partnerami). A. Łukaszenka odpowiedział D. Miedwiediewowi na premierowym

\footnotetext{
${ }^{46}$ Ibidem.

${ }^{47}$ Wojna informacyjna Rosji i Białorusi...

${ }^{48}$ Brat ty ili nie brat, „Sowietskaja Biełorussija”, 24 VI 2010.

${ }^{49}$ I. K o 1 c z i e n k o, Kak auknetsja, tak $i$ atkliknetsja, „Biełorus Siewodnjia”, 23 VI 2010.

${ }^{50}$ Kakije nużno sdielat wywody? Wzgliad iz Minska, „Narodnaja Gazieta”, 23 VI 2010.
} 
pokazie filmu Twierdza Brzeska: „Chciałoby się, żeby oni [władze Rosji] obejrzeli, przypomnieli sobie, że byliśmy w jednych okopach" ${ }^{51}$.

W pierwszej połowie września 2010 r. rosyjska rządowa stacja radiowa „Głos Rosji” zasugerowała, że w ciągu pół roku może dojść do zmiany władzy na Białorusi. Komentatorzy stacji zapowiedzieli też dalsze pogorszenie się stosunków na linii Mińsk-Moskwa. W ich opinii, sytuacja nie zmieni się, dopóki na Białorusi rządzić będzie A. Łukaszenka. Według „Głosu Rosji”, jego kontrkandydaci do fotela prezydenta powinni zaproponować FR nowy format wzajemnych stosunków, oparty na partnerstwie i pozbawiony ideologicznych podtekstów. Rosyjska stacja radiowa cytowała lidera białoruskiej opozycji Andreja Sannikowa, który uważa, że Rosja zawsze będzie strategicznym partnerem dla Białorusi, co nie zakłóci białoruskiej integracji z UE $\mathrm{UE}^{52}$.

11 i 12 września największe rosyjskie stacje telewizyjne wyemitowały szereg materiałów, oskarżających białoruskie władze o łamanie praw człowieka i zabójstwa dziennikarzy oraz oponentów politycznych. Świadczy to o dalszej eskalacji, rozpoczętej kilka miesięcy temu, rosyjskiej kampanii medialnej, która jest kolejnym instrumentem presji w polityce Kremla wobec Białorusi. Wyemitowane w wiodących rosyjskich kanałach (NTW, 1 Kanał, Rossija) programy publicystyczne - poza krytyką polityki wewnętrznej władz Białorusi oraz oskarżeniami o organizację zabójstw politycznych - zawierały również sugestie, że reelekcja A. Łukaszenki nie jest jeszcze przesądzona. Przytaczano przy tym dane anonimowych niezależnych socjologów, wskazujące rzekomo na poważne szanse wyborcze jednego z polityków białoruskiej opozycji - Uładzimira Nieklajewa, określanego przez część ekspertów jako kandydat prorosyjski ${ }^{53}$.

${ }^{51}$ W. M a r ti n o w i c z, Kupi akop. Ciena - $200 \mathrm{mln} \$$, „Bieł Gazieta”, 21 VI 2010. Premiera wspomnianego filmu miała miejsce 2 VI 2010 r. o godz. 2 w nocy (Twierdza Brzeska) i o godz. 22 (Moskwa). Film relacjonuje obronę twierdzy, która przyjęła pierwsze uderzenie niemieckich najeźdźców 22.06.1941 r. Z dokumentalną dokładnością opisano wydarzenia, które miały miejsce w pierwszych dniach obrony. Twierdza Brzeska opowiada o trzech głównych odcinkach obrony: pod dowództwem majora P. M. Gawryłowa (A. Korszunow), komisarza J. M. Fomina (P. Derewianko) oraz A. Kiżewatowa (A. Merzlikin) z 9. oddziału pogranicznego. Elementem łączącym wszystkich bohaterów jest historia Saszy Akimowa (A. Kopaszow). Właśnie oczami tego chłopaka widzimy obronę twierdzy; I. M e l n i k a u, Premiera filmu ,, Twierdza Brzeska”, www.twierdza.org (dostęp 16.09.2010); www.brestkrepost-film.com (dostęp 16.09.2010).

${ }^{52}$ Rosyjskie media: za pót roku zmiana władzy na Białorusi, www.gazeta.pl (dostęp 19.07.2010). Zdaniem W. Karbaliewicza, zaostrzenie stosunków z Rosją przed wyborami było niewygodne dla A. Łukaszenki - ceny wzrastały, ludzie niepokoili się. Określony stopień napięcia mógł działać na korzyść prezydenta Białorusi: podczas poprzednich wyborów rolę zewnętrznego wroga pełnił Zachód, aktualnie - FR. W. K a r b a l i e w i c z, Rimejk gazowoj wojny, „Swabodnyje nowostii pljus", 23-30 VI 2010.

${ }^{53}$ Eskalacja rosyjskiej kampanii informacyjnej przeciwko Łukaszence, „Tydzień na Wschodzie. Biuletyn analityczny OSW. Rosja, Kaukaz, Azja Centralna”, 15 IX 2010, nr 148, subskrypcja OSW (www.osw.waw.pl). Zob. także: Łukaszenka bardziej boi się bezrobocia niż opozycji. Biatoruś. Lider kampanii Mów Prawdę! Mówi „DGP” o nowym pomyśle na walkę z reżimem, rozmowa 
Andrzej Kublik z „Gazety Wyborczej” przyrównał sytuację „,gazowych wojen" z udziałem Gazpromu do telewizyjnych oper mydlanych, powielających wyświechtany scenariusz ${ }^{54}$.

Owszem, na całym świecie zdarzają się spory dostawców i odbiorców gazu, ale najbardziej zażarte rozstrzyga arbitraż. $Z$ tej rutyny wyłamuje się Gazprom. Rosyjski koncern od kilku lat $\mathrm{z}$ wielkim rozmachem organizuje wojny gazowe, by na własną rękę rozliczyć się z sąsiadami. Widowiska te z uwagą są obserwowane w UE, która jedną czwartą gazu importuje z Rosji. Przykręcając kurek sąsiadom, Gazprom zmniejsza też tranzyt do Europy. Od 2004 r. rosyjski koncern przeprowadził już pięć gazowych wojen - na przemian z Białorusią i Ukrainą. W tym czasie dwa razy omal nie doszło do kolejnych konfliktów. W czerwcu 2010 r. Moskwa wdała się w następną gazową wojnę z Białorusiąa ${ }^{55}$.

A. Kublik przypomniał wówczas, na czym polega spektakl wojny według Gazpromu. Zaczyna go prolog budujący napięcie -. konflikt nie może spaść nagle jak grom z jasnego nieba. Już wcześniej na horyzoncie relacji Gazpromu z jego partnerami muszą się pojawić chmury. W myśl zasady „to nie my, to oni” partnerzy Gazpromu swoim postępowaniem ściągają na siebie nieszczęście. Zgodnie z tym schematem, wczesną wiosną w rosyjskich gazetach i w międzynarodowych agencjach prasowych pojawiły się doniesienia, że Gazprom zarzuca Białorusi gromadzenie długów za gaz. Mińsk nadal unikał spłat. Podobnie Gazprom zarzucał Ukrainie, że ma długi za gaz, gdy Kijów miał jeszcze kilkanaście dni na terminowe uregulowanie rachunków ${ }^{56}$.

Ultimatum, czyli nagły zwrot akcji. W połowie czerwca rosyjska telewizja relacjonowała spotkanie prezydenta FR z A. Millerem. Szef Gazpromu żalił się, że Białorusini nie płacą długów i w tej sytuacji można im przykręcić kurek z gazem. Prezydent Rosji wydał polecenie: „Ponieważ współpracujemy z Białorusią na zasadach partnerskich, damy naszym kolegom pięć dni, aby zdecydowali, jak postępować. Zwrócicie się do kierownictwa białoruskich struktur i zaproponujecie, by jak najszybciej spłacili zadłużenie. Jeśli tego nie zrobią, trzeba podjąć surowe kroki”. Dokładnie tak samo zaczęła się gazowa wojna z Ukrainą. Pod koniec listopada 2008 r. kończono

\footnotetext{
z U. Niaklajeu, przeprowadzona przez M. Potockiego, „Dziennik Gazeta Prawna”, 12 VII 2010; Prorosyjscy i proeuropejscy przeciwnicy Łukaszenki. Białoruś. Eksperci przypuszczaja, że Rosja chce wykorzystać nadchodzace wybory prezydenckie do zdobycia większych wptywów, „Dziennik Gazeta Prawna”, 3 VIII 2010.

${ }^{54}$ A. Ku bli k, Sztuka wojny wedtug Gazpromu, www.gazeta.pl (dostęp 28.06.2010).

${ }^{55}$ Ibidem. W gazecie „7 dni” pisano: „Wielowiekowa historia Rosji pomieściła dwie Wojny Ojczyźniane, dwie światowe, jedną «zimną» i pięć energetycznych. Przy czym wszystkie pięć w ciągu ostatnich sześciu lat. I jeśli tam, gdzie lała się krew, Białorusini i Rosjanie walczyli w jednych okopach, to tam, gdzie leje się ropa i gaz, «starszy brat» wypycha młodszego na pierwszy ogień”; A. M a c e w ił o, Piataja energieticzieskaja..., „7 dniej”, 24 VI 2010.

${ }^{56}$ A. Kublik, op. cit.
} 
negocjowanie nowego kontraktu z Gazpromem. Nagle rosyjska telewizja pokazała, jak na spotkaniu z szefem Gazpromu prezydent Rosji zażądał: „Trzeba ostatecznie rozliczyć dług Ukrainy i wyegzekwować go, po dobroci albo przymusem" 57 .

Godzin a X. Przez kolejne dni po takim ultimatum Gazprom i rosyjskie urzędy ogłaszały powołanie sztabów, które będą nadzorować ograniczenie dostaw gazu krnąbrnemu partnerowi i przygotują przeniesienie tranzytu do rur w państwie nieobjętym wojną (w czasie obecnego konfliktu z Białorusią Moskwa zapowiadała zwiększenie tranzytu przez Ukrainę, przed rokiem w czasie wojny z Ukrainą Gazprom zwiększył tranzyt przez Białoruś). „Godzina X to 1 stycznia” - zapowiadał przed rokiem termin odcięcia gazu Ukrainie rzecznik Gazpromu S. Kuprijanow. W ostatnim konflikcie z Białorusią tę godzinę wyznaczono na 8.00 rano, 21 czerwca. O tej porze rosyjska telewizja transmitowała, jak prezydent Rosji wydaje polecenie zakręcenia kurka Białorusi oraz posiedzenie sztabu Gazpromu prowadzącego kampanię na Mińsk. Podobne relacje z zakręcenia kurka pokazywano w czasie wojen z Ukrainą w 2006 i 2009 r. $^{58}$

Zasłona dymna zagmatwanych kontraktów. Trzy dni przed zakręceniem kurka Białoruś ogłosiła, że Gazprom jest jej dłużny ponad $200 \mathrm{mln}$ dolarów, więcej, niż sam się domaga. Rosyjscy politycy najpierw szli w zaparte i zaprzeczali, ale Gazprom kilka godzin po zakręceniu kurka przyznał się do długów, obarczając Mińsk winą za nie. Białorusini odrzucali zarzuty. Kto zawinił postronni widzowie gazowej wojny nie rozsądzą, bo nie znają umów Gazpromu z Białorusią ${ }^{59}$.

Tranzytowe apogeum. Mińsk ogłosił, że pożyczył pieniądze na spłatę długów. Jednak Gazprom o $60 \%$ zmniejszył dostawy dla Białorusi i chociaż Mińsk przekazał pieniądze, Rosjanie utrzymali to ograniczenie do następnego dnia. W efekcie stało się tak, jak zapowiadali Białorusini - z powodu spadku ciśnienia $\mathrm{w}$ gazociągach zmniejszył się tranzyt rosyjskiego gazu na Litwę i do Polski. Zanim Gazprom odkręcił kurek, w mediach pojawiły się doniesienia, że Białoruś „podbiera” gaz, o co w poprzednich konfliktach Moskwa oskarżała

${ }^{57}$ Ibidem. W białoruskiej gazecie czytamy: „Co może powiedzieć odpowiedzialny topmenadżer, gdy partnerzy wprost oznajmiają: «Szanowny Panie! Jesteśmy wam winni określoną sumę za wzięty towar i my tę sumę zwrócimy, tak jak to robiliśmy zawsze. Ale jako że wasza firma też jest nam winna, i to o wiele większą sumę pieniędzy, to się nie denerwujcie i wszystko spokojnie sobie omówimy». Pan Miller, oczywiście z takim postawieniem problemu wewnętrznie się zgadza, ale jest on żołnierzem gazowego frontu, nad nim są dowódcy, którzy nakazują przeprowadzenie wywiadu bojowego. Logika dowódców nie jest tajemnicą. Wolą oni działać wedle kilku prostych zasad: «Albo będziecie działać w imię naszych interesów, albo wyłączymy wam gaz»”. K. P a w $1 \mathrm{j}$ u t', Miac'na gazpromskoj połowinie polia, , Sowietskaja Biełorussija”, 24 VI 2010.

\footnotetext{
${ }^{58}$ A. Kublik, op. cit.

${ }^{59}$ Ibidem.
} 
Ukrainę. Tym samym pojawił się argument na rzecz promocji omijających Europę Środkową podmorskich rur Nord Stream i South Stream ${ }^{60}$.

Rozejm w permanentnej wojnie. Mińsk i Gazprom rozliczyły się $\mathrm{z}$ długów, ale nie w pełni, ostateczne rozliczenie ma być dopiero negocjowane. W nowych umowach z pewnością znajdą się warunki, których trudno dotrzymać albo niejednoznacznie sformułowane - jak w dotychczasowym kontrakcie Mińska z Gazpromem albo w umowach rosyjskiego koncernu z Ukrainą. To chwyt scenarzysty telewizyjnej opery mydlanej, który, uśmiercając którąś postać, musi to zrobić tak, by dało się ją jeszcze ożywić. Wojen Gazpromu nigdy ostatecznie nie kończą traktaty pokojowe, ale doraźne rozejmy. Dzięki temu kiedyś znów rozpali się kolejny konflikt. Trudno powiedzieć, kiedy i o co, ale jak będzie prowadzona $-z$ góry wiadomo ${ }^{61}$.

Spór rosyjsko-białoruski przypomniał UE o problemie bezpieczeństwa dostaw gazu. W cieniu ,gazowej wojny” w Brukseli trwały polityczne uzgodnienia rozporządzenia o bezpieczeństwie dostaw gazu, należącego do najważniejszych dla przyszłości europejskiej energetyki przepisów, mającego zastąpić dyrektywę o kryzysach gazowych z 2004 r. Polska od dawna wskazywała, że można na wiele tygodni ograniczyć dostawy gazu nowym państwom UE w Europie Środkowej (zob. wykres 1), a według dyrektywy formalnie nie będzie kryzysu. Prace nad nowymi przepisami ruszyły dopiero po wojnie gazowej Rosji z Ukrainą zimą zeszłego roku. Wtedy Gazprom na trzy tygodnie wstrzymał tranzyt gazu przez Ukrainę do Europy, aby zmusić Kijów do wyższej zapłaty za niego. Wiosną europarlament przyjął projekt rozporządzenia przyznającego KE kluczową rolę w razie kryzysu i wprowadzenie mechanizmów solidarnego działania, aby państwa pozbawione gazu miały pewność, że dostaną go od innych członków Unii. Propozycje europarlamentu zaczęły jednak osłabiać unijne rządy ${ }^{62}$.

Poszczególne kraje zazdrośnie strzegły swoich dostaw gazu, dążąc np. do rozszerzenia grupy „odbiorców wrażliwych” na różne zakłady przemysłowe. Definicja tych odbiorców jest kluczowa w razie kryzysu, gdyż trzeba im zapewnić dostawy w pierwszej kolejności, a dopiero ewentualną nadwyżką podzielić się z innym krajem UE, będącym w potrzebie. Polska bezskutecznie postulowała, by grono „odbiorców wrażliwych” ograniczyć do żłobków, szkół czy szpitali przyjęty kompromis zakłada szeroką definicję, co w praktyce oznacza, że kraje same zadecydują, kogo zaliczą do tej kategorii. Polski rząd przyznał, że był w tej kwestii osamotniony w Radzie UE ${ }^{63}$.

\footnotetext{
${ }^{60}$ Ibidem.

${ }^{61}$ Ibidem. Zob. także: W. D o b row, Gazowyj konflikt: w czjih intieriesach. Wzgliad iz Maskwy, „Narodnaja Gazieta”, 23 VI 2010.

${ }^{62}$ A. K u blik, UE zrobiła krok ku solidarności wobec gazowych kryzysów, www.gazeta.pl (dostęp 14.09.2010).

${ }^{63}$ UE: Porozumienie w sprawie bezpieczeństwa dostaw gazu osiagnięte, www.gazetaprawna. pl (dostęp 14.09.2010).
} 
Wykres 1. Uzależnienie krajów UE od importu gazu

\section{Kraje UE są mocno uzależnione od importu gazu}

\section{Rosja ma decydujący wpływ na bezpieczeństwo energetyczne większości sąsiadów Polski}

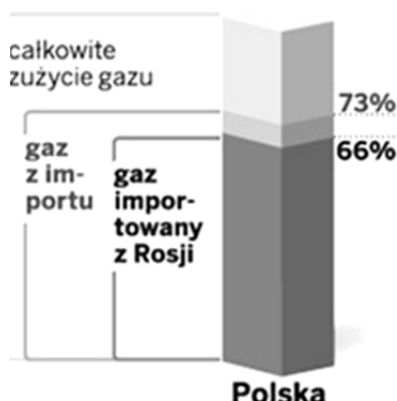

Polska

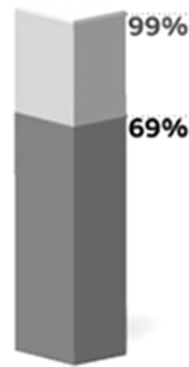

Czechy

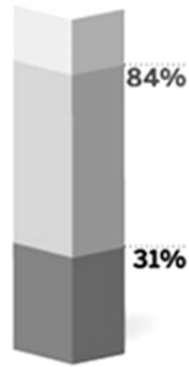

Niemcy

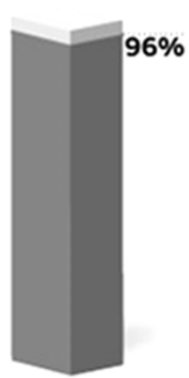

Słowacja

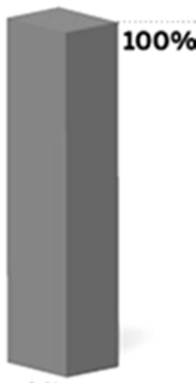

Litwa

Źródło: M. D u s z c z y k, Solidarność energetyczna? Unia wykreśliła to z rozporządzenia. Surowce. Rozwiązania niekorzystne dla Polski, www.gazetaprawna.pl (dostęp 14.09.2010).

Zgodnie z kompromisowym stanowiskiem ${ }^{64}$, projekt rozporządzenia zakłada m.in., że UE będzie zobligowana do działań mających zapobiec kryzysowi już na etapie wczesnego ostrzegania. Jeśli dyplomatom z Brukseli nie uda się zażegnać kryzysu, UE będzie mogła uruchomić mechanizmy tzw. solidarności energetycznej. W praktyce oznacza to, że gdy np. Moskwa zakręci kurek z gazem, surowiec dostarczą nam m.in. Niemcy (zgodnie z nowymi przepisami, na żądanie dwóch państw KE będzie musiała wprowadzić unijny stan kryzysowy). Aby to było możliwe, zamierza ona monitorować zgodność krajowych planów kryzysowych, a także koordynować działania względem państw trzecich w przypadku wystąpienia sytuacji kryzysowej. Poza tym w rozporządzeniu podkreślono zakaz łamania unijnego prawa konkurencji, w tym wpisywania do umów o dostawę surowca tzw. klauzul przeznaczenia (możliwy będzie reeksport gazu). Rozporządzenie zakłada również generalną regułę określającą, że systemy przesyłowe mają być w miarę możliwości dwukierunkowe (w konsekwencji Polska powinna móc odbierać w razie potrzeby rosyjski gaz kupowany przez Niemcy tzw. rewersem na

${ }^{64}$ Głosowanie nad przyjęciem rozporządzenia zaplanowano na posiedzeniu 20-23 IX 2010 (na drugiej sesji plenarnej w Strasburgu). Co prawda istniała możliwość wniesienia jeszcze przed głosowaniem ostatnich ustnych poprawek do projektu rozporządzenia, ale raczej nikt w ostatniej chwili nie decydował się na zmianę jego kształtu. Następnie w grudniu rozporządzenie trafiło pod obrady RE. M. D u s z c z k, W tym miesiącu rozstrzygnie się gazowa przyszłość Europy, www. gazetaprawna.pl (dostęp 14.09.2010). 
rurociągu jamalskim $)^{65}$. Wprowadza ponadto skomplikowany wzór, na podstawie którego wylicza się bezpieczeństwo gazowe danego kraju (tzw. formuła $\mathrm{N}-1$ ). Za bezpieczny kraj uznaje się ten, który w przypadku, gdy ulegnie awarii główny element infrastruktury sieciowej, zapewni zdolność przesyłową pozostałych elementów sieci na poziomie odpowiadającym dziennemu zapotrzebowaniu (równy najwyższemu dobowemu zużyciu z ostatnich 20 lat). Państwa członkowskie będą musiały spełnić ten warunek ${ }^{66}$.

$\mathrm{Na}$ dostosowanie się do znajdujących się w projekcie rozporządzenia wymagań (m.in. rozbudowę pojemności magazynowych, zapewnienie technicznych możliwości odwrotnego przesyłania w sieci, rozbudowę połączeń ze zintegrowaną europejską siecią gazową i doprowadzenie do uniezależnienia się od pojedynczego dostawcy z kraju trzeciego) członkowie wspólnoty mają 4 lata ${ }^{67}$.

Połączenia transgraniczne z sieciami innych państw członkowskich muszą być zapewnione najpóźniej w 3 lata od wejścia w życie rozporządzenia. Nowa regulacja podzieli poza tym Europę na regiony. Polska znajdzie się w dwóch - z Niemcami oraz z krajami bałtyckimi. W praktyce oznacza to, że należy wybudować np. połączenie z siecią gazową Litwy. Wstępny projekt interkonektora, którego wartość szacowana jest na około $1 \mathrm{mld} z$ z, jest już gotowy. Rurociąg, który mógłby tłoczyć 2 mld $\mathrm{m}^{3}$ gazu rocznie $\mathrm{w}$ obie strony, miałby zostać uruchomiony w ciągu kilku lat. Do połowy 2014 r. w Świnoujściu powstanie gazoport, którym będziemy im-

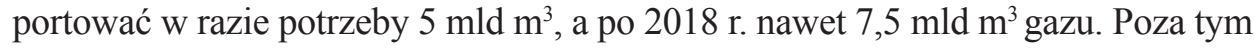
rozbudowujemy połączenia z Niemcami. Możliwości importu z Niemiec wzrosły do października 2011 r. z 0,9 do $1,5 \mathrm{mld} \mathrm{m}^{3}$ rocznie. W ciągu 4-5 lat powstanie też gazociąg Boernicke-Police (2-3 mld $\left.\mathrm{m}^{3}\right)$. Również w październiku 2011 r. został uruchomiony łącznik Moravia z siecią czeską $\left(0,5 \mathrm{mld} \mathrm{m}^{3}\right)^{68}$.

Nowa regulacja jest aktem przełomowym. Nie wszystkie jej zapisy są jednak zgodne z polskimi postulatami. Europosłowie przyznają, że dokument wypracowany w czasie trilogów (rozmów między Komisją, Parlamentem i Radą Europejską) jest kompromisowy. Niestety, kilka kluczowych zapisów, istotnych z polskiego punktu widzenia, wypadło z projektu. Najważniejszy, na którym nam zależało, ale nie znalazł się w dokumencie, mówił o uruchamianiu mechanizmów solidarności energetycznej w momencie, gdy dostawy surowca do regionu spadną o co najmniej $10 \%$. Zastąpił go nowy paragraf, zgodnie z którym o pomoc może zwrócić się każdy kraj członkowski, ale decyzja o uruchomieniu mechanizmów solidarnościowych nie będzie automatyczna, podejmie ją KE. W razie kryzysu nie mielibyśmy zatem pewności, że otrzymamy pomoc gazową. Nie udało się też przeforsować wąskiej definicji odbiorców chronionych (Polska chciała, by

\footnotetext{
65 Ibidem.

66 Ibidem.

${ }^{67}$ Ibidem.

${ }^{68}$ Ibidem.
} 
do tej grupy zaliczano tylko przedszkola, żłobki, szpitale, wygrała jednak opcja, która zakłada, że kraje same będą decydować, czy włączyć do tej grupy np. zakłady przemysłowe). W efekcie może się okazać, że uzyskanie pomocy gazowej od sąsiedniego kraju będzie trudne, ponieważ w pierwszej kolejności będzie on zaspokajał potrzeby własnych odbiorców chronionych. Po stronie porażek musimy zapisać wyrzucenie z projektu artykułu traktującego priorytetowo budowę gazociągu Nabucco (został on złagodzony i uzupełniony o mechanizm wspierania innych projektów w UE) oraz mówiącego o wzmocnieniu roli KE w sytuacjach alarmowych, m.in. poprzez włączenie do procesu reagowania na kryzysy gazowe wysokiego przedstawiciela ds. polityki zagranicznej ${ }^{69}$.

W kontekście negocjacji nowej umowy gazowej między RP a FR trzeba pamiętać, że bezpieczeństwo energetyczne, oparte na przyjętych przez Unię zasadach (m.in. oddzielenie operatorów gazociągów od dostawców gazu i otwarcie sieci dla wszystkich chętnych) jest długofalowym interesem Polski, a nawet warunkiem niezależności jednego producenta węglowodorów (Rosji). Warto zaryzykować wojnę gazową, by nie torpedować bezpieczeństwa energetycznego. A. Talaga słusznie pyta: „Jaką będziemy mieć wiarygodność, kiedy najpierw zaciekle walczymy o niezależność gazową, a potem jako pierwsi kapitulujemy?" Wcale nie jest powiedziane, że Moskwa podejmie rękawicę. Wojna gazowa z członkami UE nie wplata się w kremlowską politykę zbliżenia $z$ Unią i byłaby fatalnie przyjęta w europejskich stolicach. Być może Rosji bardziej opłaca się kompromis z Polakami niż zmuszenie nas do przyjęcia warunków Gazpromu ${ }^{70}$.

Tymczasem strona polska, w sposób nie do końca przejrzysty - choć, z uwagi na poufność negocjacji, można ją przynajmniej częściowo w tym względzie „rozgrzeszyć" - przygotowała się do podpisania z Gazpromem umowy ${ }^{71}$, która daje mu do 2045 r. monopol na tranzyt gazu jamalską rurą przez RP i ulgowe opłaty za tranzyt gazu, wyliczane w nieprzejrzysty sposób. Umowa zwiększa także ilość

\section{${ }^{69}$ Ibidem.}

${ }^{70}$ A. Ta 1 a g a, Polska $w$ oparach gazu, czyli co jest $w$ naszym interesie, „Dziennik Gazeta Prawna”, 8 IX 2010. Zob. także: W Polsce gaz jest tańszy niż w krajach ościennych, rozmowa z Michałem Szubskim - prezesem PGNiG, przeprowadzona przez M. Piaseckiego, P. Sołtysa, „Dziennik Gazeta Prawna”, 1 IX 2010. Wspomniany już wcześniej gazociąg Nabucco ma transportować gaz z Iranu, Azerbejdżanu, Rosji lub wschodniej części Turcji do Austrii, przez Bułgarię, Rumunię i Węgry. Stanowi konkurencję dla South Stream'u - stąd FR w różny sposób próbuje torpedować projekt (np. kupując gaz od Azerbejdżanu). Zob.: Banki dołożą się do Nabucco, „Dziennik Gazeta Prawna”, 7 IX 2010; D. M a 1 i n o w s k i, Mniej gazu dla Nabucco?, www.wnp.pl (dostęp 16.09.2010); i d e m, Bez gazowej solidarności w regionie, www.wnp.pl (dostęp 16.09.2010).

${ }^{71}$ Geneza planowanej, długoterminowej umowy w sprawie dostaw rosyjskiego gazu do Polski sięga przełomu lat 2008-2009, kiedy wybuchł rosyjsko-ukraiński spór gazowy. Zawarte w styczniu 2009 r. porozumienie między rosyjskim Gazpromem a Naftohazem wyeliminowało z pośrednictwa w handlu surowcem spółkę RosUkrEnergo, co spowodowało obniżenie dostaw gazu do Polski. Pojawiła się potrzeba uzupełnienia tych dostaw poprzez podpisanie nowej umowy. Kalendarium polsko-rosyjskiej umowy gazowej, PAP, za: http://forsal.pl (dostęp 14.09.2010). 
importowanego z Rosji gazu z 7,5 do $10,3 \mathrm{mld}^{3}$ paliwa rocznie. Wydłuża ona także czas obowiązywania kontraktu o 15 lat, czyli do 2037 r. ${ }^{72}$

Na taką umowę nie zgadza się Komisja Europejska, grożąc Polsce procesem w Europejskim Trybunale Sprawiedliwości. KE domaga się, aby warunki przesyłania surowca ustalał operator niezależny od Gazpromu i PGNiG. Powinien móc zarobić na tej operacji na tyle dużo, by inwestować w modernizację sieci. Jest to tak ważne dla Brukseli, ponieważ chodzi o to, aby z gazociągu jamalskiego mogli korzystać także inni dostawcy gazu. To warunek realnej konkurencji na rynku i jednoczesnej poprawy bezpieczeństwa energetycznego w całej UE. Co prawda poprzez gazociąg jamalski tłoczony jest surowiec tylko z Rosji, jednak w ramach tzw. operacji swap jakikolwiek europejski koncern może zaoferować Polsce gaz za niższą cenę i wywiązać się z porozumienia, dostarczając surowiec z Rosji. Bruksela stawia sprawę na ostrzu noża, bo porozumienie polsko-rosyjskie ma wygasnąć dopiero za 35 lat - przez ten czas sprawa byłaby zablokowana ${ }^{73}$.

Zdaniem Nicole Bockstaller, jednej z rzeczniczek Komisji Europejskiej, jeśli Polska podpisałaby porozumienie, które łamie reguły tzw. dyrektywy gazowej, Bruksela może pozwać nasz kraj przed Europejski Trybunał Stanu. Ze względu na długość procedur takie spory rzadko kończą się nałożeniem kar na kraje członkowskie. Tym razem może być inaczej - umowa z Rosjanami ma obowiązywać aż 35 lat i nawet unijne procesy tak długo nie trwają. Rząd D. Tuska znalazł się w potrzasku: $z$ jednej strony jest naciskany przez Unię, z drugiej ma świadomość, że w razie wstrzymania dostaw przez Gazprom nie ma przed zimą alternatywnego źródła gazu. Wciąż nie działa gazoport, nie ma też łącznika z niemiecką siecią gazową, który zapewniłby nam możliwość importu surowca od innych krajów UE. Niemiecki koncern E.ON zaproponował niedawno Polsce sprzedaż nadwyżek gazu, który zakontraktował z Rosji. Musiałby jednak do tego wykorzystać gazociągi biegnące do naszego kraju bądź przez Białoruś, bądź przez Ukrainę. Na żadne z tych rozwiązań nie zgodził się Gazprom ${ }^{74}$.

72 M. D u s z c z y k, Gaz: bezpieczni będziemy dopiero w 2015 r., „Dziennik Gazeta Prawna”, 8 IX 2010; J. B i e le c k i, Bruksela stawia Polskę pod ściana, „Dziennik Gazeta Prawna”, 1 IX 2010; Niemcy ratuja nas przed Rosja, „Dziennik Gazeta Prawna”, 6 IX 2010.

${ }^{73} \mathrm{~J} . \mathrm{B}$ i e 1 e c k i, Bruksela....

${ }^{74}$ Umowę na dostawy gazu E.ON Ruhrgas zawarł z PGNiG 3 V 2011 r. „Paliwo miało być dostarczane od początku czerwca do końca 2011 r. Dostawy zamierzano realizować przez punkt zdawczo-odbiorczy w Drozdowiczach na granicy polsko-ukraińskiej” - mówi Joanna Zakrzewska, rzecznik PGNiG. Jednak niemiecki koncern nie uzyskał zgody ukraińskiego operatora na przesyłanie paliwa do Polski. W rzeczywistości sprawa jest bardziej skomplikowana, bo ukraińskie sieci są uzależnione od Rosji. Aby Ruhrgas mógł pompować błękitne paliwo E.ON w Drozdowiczach do Polski, powinien się porozumieć z Gazpromem, któremu jednak bardziej się opłaca zawrzeć nową, długoterminową umowę z Polską, niż przejmować się kłopotami niemieckiego giganta. Z powodu braku możliwości dostarczenia paliwa do Polski 28 lipca PGNiG i Ruhrgas podpisały aneks. Zakłada on, że umowa zostanie sfinalizowana 1 października. Jeśli ukraiński operator nadal nie będzie się zgadzał na przesyłanie gazu do Polski, E.ON Ruhrgas będzie mógł wykorzystać prawo unijne, którego stosowania 
Polska obawia się także, że w razie niepodpisania umowy Rosjanie prędzej czy później przestaną tłoczyć gaz przez Jamal, a wówczas będziemy uzależnieni wyłącznie od dostaw poprzez Nord Stream, który ma zacząć działać za trzy lata. Niektórzy eksperci twierdzą nawet, że Komisja Europejska przyjęła wobec Polski tak zdecydowaną postawę właśnie pod naciskiem Berlina. Połączona pojemność gazociągów jamalskiego i bałtyckiego jest zbyt duża w stosunku do zapotrzebowania $\mathrm{UE}^{75}$.

„Kommiersant”, powołując się na anonimowe źródła w koncernie, napisał, że Gazprom traktuje żądania UE jako próbę „wywłaszczenia” z gazociągu jamalskiego. „Rosja nie jest członkiem UE i nie ma obowiązku dostosowywania swoich dwustronnych relacji w sferze energetycznej do prawa UE" - powiedział rosyjskiemu dziennikowi przedstawiciel Gazpromu. Te zarzuty stanowczo odrzuciła KE. Unijne regulacje energetyczne muszą być stosowane przez firmy działające na terenie UE, tak jak firmy europejskie działające w Rosji muszą przestrzegać zasad rosyjskich - powiedziała rzeczniczka G. Oettingera Marlene Holzner, cytowana przez PAP. „Kommiersant” sugerował ponadto, że Gazprom może wywrzeć presję na Polskę, bo bez nowej umowy może nam zabraknąć gazu na zimę ${ }^{76}$.

w Polsce domaga się komisarz G. Oettinger, nawiasem mówiąc, Niemiec. Gdy operatorem gazociągu zostanie Gaz-System, dopuści do niego innych dostawców niż Gazprom. „Wtedy niemiecki koncern będzie mógł sprzedać w Polsce część paliwa płynącego na Zachód" - przyznaje Piotr Woźniak, były minister gospodarki, a obecnie szef rady ACER, unijnej agencji energetycznej. Na przeprowadzenie takiej operacji nie będzie potrzebna zgoda Gazpromu. Jak zauważa Janusz Kowalski, były członek zespołu ds. bezpieczeństwa energetycznego w Kancelarii Prezydenta, „w polskim interesie jest wyłącznie zabezpieczenie dostaw do momentu otwarcia gazoportu, a więc do połowy 2014 r.”. Rzeczywiście, od 2015 r. Polska będzie już krajem znacznie bardziej bezpiecznym pod względem zaopatrzenia w gaz. Jeśli nie podpiszemy z Gazpromem nowego kontraktu, lecz wciąż będzie obowiązywał dotychczasowy, na rynku i tak pojawi się prawie $20 \mathrm{mld} \mathrm{m}^{3}$ gazu rocznie, czyli o około $6 \mathrm{mld} \mathrm{m}^{3}$ więcej, niż zużywamy obecnie i co najmniej o $2 \mathrm{mld}^{3}$ więcej, niż będziemy potrzebowali za 5 lat. Nadal będziemy jednak uzależnieni od rosyjskiego gazu. Istnieje bowiem ryzyko, że w razie całkowitego wstrzymania dostaw ze Wschodu zabraknie nam około jednej trzeciej niezbędnego surowca. Dziś rosyjskie paliwo w bilansie gazowym Polski stanowi aż $66 \%$. W sumie sprowadzamy $73 \%$ potrzebnego nam gazu. Krajowe wydobycie od lat oscyluje wokół poziomu $4 \mathrm{mld} \mathrm{m}^{3}$ i nic nie wskazuje na to, by w najbliższym czasie miało się coś w tej kwestii zmienić. $\mathrm{O}$ ile badania potwierdzą występowanie w Polsce gigantycznych złóż gazu łupkowego, o tyle ich eksploatacja będzie mogła ruszyć dopiero po roku 2020. Do tego czasu, czy tego chcemy, czy nie, jesteśmy skazani na gaz z Rosji. Mimo uzależnienia od dostaw tego surowca ze wschodu, pod względem bezpieczeństwa energetycznego Polska na tle UE wygląda całkiem nieźle. Wszystko dzięki... węglowi. Zależność naszego kraju od nośników energii z importu wynosi zaledwie 32\%. To mniej niż np. w Niemczech, we Włoszech czy Hiszpanii. M. D u s z c z y k, Gaz...; J. B i e l e c k i, Bruksela ...; Niemcy ratuja nas ...; Gazoport w Świnoujściu będzie, nawet bez kasy z UE, IAR/Puls Biznesu, za: http://wiadomosci.wp.pl (dostęp 14.09.2010); http://portzewnetrzny.pl (dostęp 14.09.2010).

${ }^{75} \mathrm{~J}$. B i e l e c ki, Bruksela...

${ }^{76}$ A. K ublik, Polska chce renegocjować umowe gazowa z Rosją, www.gazetaprawna.pl (dostęp 14.09.2010). 18 września 2010 r. w Moskwie zakończyła się pierwsza runda polsko-rosyjskich negocjacji gazowych z udziałem przedstawiciela KE: strony „osiągnęły zbliżenie stanowisk” 
Czy tak będzie? Czy czeka nas spór, podobny do tego z czerwca br. [2010] między Rosją a Białorusią? Czy może demonizujemy potęgę Gazpromu? Owszem, działa on często na zamówienie polityczne Kremla, ale... Jak to się dzieje, że Ruhrgas, Total, Wintershall i N. V. Nederlandse Gasunie wiążą swój los z Moskwą, nie obawiają się Rosjan? Dla nich to czysty układ - oni płacą, Gazprom dostarcza paliwo. Żadnej polityki, mieszania biznesu z imperialnymi celami. Wobec nich Gazprom wywiązuje się ze zobowiązań, a w polityce wobec Ukrainy i Białorusi kieruje się zrozumiałymi dla wszystkich kryteriami - egzekwuje umowy, odcina paliwo, jeśli odbiorcy nie chcą płacić wynegocjowanych cen, które na ogół są i tak niższe niż te dla odbiorców zachodnich ${ }^{77}$. To fakt, tyle tylko, że spory powstające w przestrzeni postradzieckiej, których jedną ze stron jest FR, zazwyczaj mają co najmniej jedno „drugie dno" ${ }^{78}$. Nie inaczej było w przypadku sporu sprzed kilku miesięcy.

- głosił komunikat polskiego resortu gospodarki. Z komunikatu wynika, że „klimat rozmów był sprzyjający" i konsultacje będą kontynuowane. Zabrzmiało to optymistycznie, ale KE przygotowuje się na najczarniejszy scenariusz. Rzeczniczka Komisji Marlene Holzner powiedziała, że Bruksela jest świadoma zagrożeń i kłopotów z dostawami gazu, ale ma nadzieję je zażegnać. „Jak wiadomo staraliśmy się zmienić unijne prawo z myślą o takich problemach. Poprosiliśmy kraje członkowskie o gromadzenie zapasów gazu, poza tym kilka państw może pospieszyć z pomocą. Nie mówimy o zimie, ale o okresie jesiennym. Pracujemy z polskim rządem nad różnymi scenariuszami i możliwymi rozwiązaniami" - dodała. Komisja Europejska przygotowuje się na najczarniejszy scenariusz, www. psz.pl (dostęp 18.09.2010); Koniec pierwszej rundy negocjacji gazowych z udziałem przedstawiciela KE, IAR, www.psz.pl (dostęp 18.09.2010).

77 A. Ta l a g a, Wiek gazu, ale nie Gazpromu, „Dziennik Gazeta Prawna”, 25-27 VI 2010.

${ }^{78}$ Niepewni politycznie klienci muszą regulować swoje należności natychmiast pod groźbą zakręcenia kurka. Sprzymierzeńcy albo płacą za surowiec grosze, albo mogą zadłużać się w nieskończoność. Rekordy biją separatyści z Tyraspola. Dług Naddniestrza wobec Gazpromu na początku roku [2010] przekroczył 2 mld dol. To kwota dziesięciokrotnie wyższa od zadłużenia Białorusi. Tymczasem Moskwa już w połowie czerwca groziła Mińskowi odcięciem dostaw. Wobec Naddniestrza koncern nie zamierza stosować rynkowej logiki. „Naddniestrze to nasz największy dłużnik” - przyznała w rozmowie z „Dziennikiem Gazeta Prawna” Tatjana Gołubowicz z centrum prasowego Gazpromu. Zaraz jednak dodała, że nie ma planu ściągania przez koncern należności. Co ciekawe, formalnie za dostawy do separatystów powinna zapłacić tocząca spór Tyraspolem Mołdowa, na której ciążą zobowiązania. Rząd w Kiszyniowie uznaje Naddniestrze za integralną część państwa. Zrzucając na nie odpowiedzialność za długi, potwierdziłby niezależność prorosyjskiego terytorium. Tyraspol również nie uznaje zadłużenia. Prezydent Naddniestrza Igor Smirnow uprzedził, że za rachunki zapłaci dopiero wtedy, gdy podpisze bezpośrednią umowę odnośnie do dostaw surowca z Gazpromem. Dotychczas rosyjski gaz płynął do Naddniestrza za pośrednictwem Mołdowagazu. Dla porównania: w połowie czerwca dostawy gazu dla Białorusi zostały częściowo wstrzymane ze względu na dług w wysokości „,zaledwie” 200 mln dol. Ukrainie - z zadłużeniem o pół miliona dolarów mniejszym niż naddniestrzańskie - odcięto dopływ surowca w styczniu 2009 r. „Przymknięcie oka na Naddnistrze przez Gazprom to zapłata za lojalność. Naddniestrze stanowi prokremlowską enklawę, gdzie od dwudziestu lat stacjonują rosyjskie wojska. Warto tam inwestować" - powiedział „DGP” politolog z Tyraspola Andriej Safonow - „Kreml wie, że utrata wpływów w Naddniestrzu wiąże się z utratą pozycji strategicznej w całym regionie Europy Południowo-Wschodniej”. N. D ż i k i j a, Lepsi i gorsi dlużnicy Gazpromu, „Dziennik Gazeta Prawna”, 2 VIII 2010. Co do ta- 
Kiedy Gazprom przykręcił Białorusi kurek z gazem, wystarczyły dwa dni, by Mińsk spłacił zadłużenie wobec rosyjskiego giganta. Być może, jak zauważa P. Talaga, gaz stanie się paliwem XXI w., a jednocześnie przestanie funkcjonować jako narzędzie polityczne. Wprawdzie wskutek kryzysu jego zużycie w Europie spada, ale perspektywy są wciąż obiecujące ${ }^{79}$.

Dyrektorzy operacyjni koncernów energetycznych, zebrani w połowie czerwca 2010 r. na Europejskim Kongresie Biznesu w Cannes, nie mieli wątpliwości, że czysta gospodarka, jeśli chce się rozwijać, musi sięgnąć po gaz. Na spotkaniu triumfował A. Miller: „Świat zwróci się ku paliwom bardziej wydajnym i przyjaznym środowisku, a gaz ziemny będzie odgrywał w tym procesie znaczącą rolę". Obalał też mity. Pierwszy, najbliższy polskim sercom, to gaz łupkowy. Zdaniem Millera, ma on tylko znaczenie lokalne, wpłynął wprawdzie na rynek amerykański, w Europie jednak nie zastąpi gazu tradycyjnego. Ta pewność ma podstawy. Szacunki amerykańskich firm zakładają, że zasoby gazu łupkowego w Polsce sięgają 1,5 bln $\mathrm{m}^{3}$. Gdyby rozpocząć ich eksploatację, w 2015 r. wydobycie wynosiłoby miliard metrów sześciennych. To ledwie jedna czternasta obecnego zapotrzebowania na gaz, a będzie ono przecież rosło. „Gaz łupkowy jest trudniejszy w wydobyciu niż konwencjonalny, wszystko zależy od składu skał, jedne umożliwiają tanią eksploatację, inne nie. Kolejny problem to gęstość zaludnienia. $\mathrm{Na}$ obszarach pustych można dokonywać wielu odwiertów, czego wymaga technologia eksploatacji łupków. Na pokrytych osiedlami już nie" - thumaczył Richard Guerrant, dyrektor marketingu europejskiego oddziału Exxon Mobil. Drugi mit to gaz płynny. ,Jego udział w rynku rośnie, ale jest on zużywany głównie wzdłuż wybrzeży, w niewielkiej odległości od terminali" - argumentował Miller. Gdyby transportować go w głąb lądu na duże odległości, cena wzrośnie, trzeba by bowiem zbudować nową sieć transportu. Słowa szefa Gazpromu znów nie są bezpodstawnym czarnowidztwem. Polska chce uruchomić w 2014 r. gazoport, dzięki któremu docelowo będziemy sprowadzać $7 \mathrm{mld}^{3}$ gazu rocznie, czyli połowę obecnego zapotrzebowania. Wątpliwe jednak, by był on zużywany na południu kraju, straty przesłowe podbiłyby bowiem jego cenę do poziomu wyższego niż tradycyjnie transportowany gaz rosyjski. Wreszcie trzeci mit: przyszłość energetyki należy do źródeł odnawialnych. Jakich inwestycji trzeba by dokonać, by zastąpić ropę, węgiel i gaz jako główne źródła energii? Europejskie rządy tną wydatki i administrację, więc żaden z nich nie wyłoży w najbliższych latach setek miliardów euro na rewolucyjne rozwiązania technologiczne, które wciąż nie udowodniły swojej efektywności. Przyszłość, przynajmniej ta niezbyt odległa, nie

kiego osądu sprawy nie miała też wątpliwości dziennikarka „Komsomolskoj Prawdy na Biełarusi”. Stwierdziła, że „Gazowy szantaż ze strony Gazpromu wciąż, jak dawniej, pozostaje środkiem realizacji celów politycznych Kremla”. T. M a n i e n o k, Uchodim w mazut?, „Komsomolskaja Prawda w Biełarusi", 23 VI 2010.

${ }^{79}$ A. Ta 1 a g a, Wiek gazu... 
będzie należała do źródeł odnawialnych, staną się one jedynie uzupełnieniem tradycyjnych dostaw energii ${ }^{80}$.

Dziennikarz „DGP” zauważa jednak, że w słowach A. Millera słychać niepokój. Trzy obalone przez niego mity, dotyczące gazu łupkowego, gazu płynnego i energii odnawialnej, łączy jedno - wszystkie wymagają nowych technologii, inwestycji i innowacyjności. Nie jest to rosyjska specjalność. Konkludując: szef koncernu ma rację, nie dojdzie do rewolucji łupkowej, detronizującej Gazprom, którego rola i tak będzie stopniowo malała w obliczu wielu inwestycji i ruchów cenowych na światowych rynkach. Exxon Mobil szacuje, że w roku 2020 rosyjski gaz zaspokoi tylko $10 \%$ zapotrzebowania Starego Kontynentu na ten surowiec (to tyle, ile wynoszą dostawy z Turkmenii czy rejonu Australazji), a kolejne 20\% wypełni gaz łupkowy z USA. Gazprom stanie się jednym z wielu dostawców, ani mniej, ani bardziej istotnym niż inni. To wciąż niezła perspektywa dla rosyjskiego giganta, daleka jednak od wizji eurazjatyckiego monopolisty. Wiek XXI będzie należał do gazu, ale nie do Gazpromu ${ }^{81}$.

${ }^{80}$ Ibidem.

${ }^{81}$ Ibidem. Spadek dochodów Gazpromu spowodowany kryzysem i utrzymujące się poważne zadłużenie koncernu (przeszło 60 mld dolarów, według skonsolidowanego sprawozdania finansowego za rok 2009) spowodowało redukcję planowanego budżetu inwestycyjnego o 30\%, głównie kosztem odroczenia terminów realizacji projektów wydobywczych (m.in. gazociągów Jamalskiego i Sztokmanowskiego). Wydatki na strategiczne projekty rurociągowe (w tym Nord Stream i South Stream) z budżecie 2009 i w projekcie budżetu na 2010 r. pozostały jednak na zaplanowanym poziomie, co wynika z przekonania o tymczasowości obecnego kryzysu i optymistycznych prognoz Gazpromu co do wzrostu eksportu od 2010 r. i wzrostu cen gazu od roku 2012. Kierownictwo koncernu deklaruje wolę przeciwdziałania w przyszłości próbom rewizji warunków kontraktów długoterminowych, nie rezygnuje z planów przejęcia 10-20\% rynku gazowego USA, 1/3 rynku UE i zapowiada awans Gazpromu do rangi globalnego holdingu energetycznego. Prognozy innych ośrodków nie uzasadniają tego optymizmu. Z badań Międzynarodowej Agencji Energetyki wynika, że niekorzystne dla eksporterów tendencje - nadpodaż gazu i niższe od kontraktowych ceny na rynku sportowym - mogą się utrzymać do 2015 r. Niemiecki koncern RWE przewiduje ustabilizowanie się udziału rosyjskiego surowca w rynku europejskim do 2020 r. na poziomie $20-22 \%$. Zdaniem Cambridge Energy Research Associates, rynek amerykański będzie w średniej perspektywie praktycznie zamknięty dla importu rosyjskiego gazu. Mniejszy z powodu kryzysu popyt na gaz i zmiana sytuacji na rynku gazowym spowodowały spadek wyników produkcyjnych i finansowych Gazpromu. Podważyły też podstawy gazpromowskiej strategii ekspansji, m.in. tezy o stałym, nabierającym przyspieszenia wzroście popytu na rosyjski gaz w Europie, nieuchronnym wzroście cen surowca i bezalternatywności dostaw gazu z Rosji. Nadpodaż tańszego gazu płynnego oraz realizacja unijnej polityki dywersyfikacji i energooszczędności nie daje szans szybkiej odbudowy korzystnej dla eksporterów gazu koniunktury. Przy słabej nadziei na wzrost cen Gazprom będzie poddawany rosnącej presji odbiorców, aby zrewidować warunki kontraktów długoterminowych. Utrzymanie się obecnych tendencji może też wymusić korektę polityki ekspansji koncernu w Europie. E. P a s z y c, Kryzys uderza w strategię Gazpromu, „Tydzień na Wschodzie. Biuletyn analityczny OSW. Rosja, Kaukaz, Azja Centralna", 7 VII 2010, nr 24, subskrypcja OSW (www.osw.waw.pl); Mimo kryzysu Gazprom zwiększy inwestycje o ponad 3 mld USD, epa, ,Tydzień na Wschodzie. Biuletyn analityczny OSW. Rosja, Kaukaz, Azja Centralna”, 15 IX 2010, nr 30, subskrypcja OSW (www.osw.waw.pl). 
Ze względu na swoje strategiczne znaczenie ropa naftowa i gaz ziemny odgrywały i odgrywają istotną rolę w polityce zagranicznej wielu państw świata. Trzeba pewnie pogodzić się z tym, że również we współczesnej Rosji eksport ropy i gazu został uznany za instrument polityki ${ }^{82}$. Stało się tak, chociaż - jak stwierdził kiedyś znany i wpływowy politolog Siergiej Karaganov ${ }^{83}$ - „wykorzystywanie ropy i gazu jako instrumentów polityki zagranicznej jest absolutnie niedopuszczalne”. Jednocześnie dodawał, że „,nierobienie tego jest też absolutnie niemożliwe". Trzeba się więc przyjąć, iż w stosunkach międzynarodowych będziemy mieli do czynienia z takimi instrumentami uprawiania polityki. Mogą one funkcjonować do czasu, kiedy korzystanie z nich nie szkodzi interesom partnerów i nie staje się swego rodzaju ,energetyczną bronią" ${ }^{84}$, tak jak w przypadku opisywanego sporu rosyjsko-białoruskiego z czerwca $2010 \mathrm{r}$.

${ }^{82}$ A. K u p i c h, [recenzja] Geopolityka rurociagów. Wspótzależność energetyczna a stosunki międzynarodowe na obszarze postsowieckim, red. E. Wyciszkiewicza, Warszawa 2008, za: www. pism.pl (dostęp 17.09.2010).

26 listopada 2009 r. rząd Rosji ostatecznie zatwierdził Strategię energetyczną Federacji Rosyjskiej do 2030 r. Zakłada ona znaczący wzrost wydobycia i eksportu surowców energetycznych oraz jednoczesną modernizację tego sektora i zmniejszenie udziału kompleksu paliwowo-energetycznego w rosyjskim PKB (na skutek dywersyfikacji oraz gruntownej modernizacji całej gospodarki). Dokument deklaruje również zwiększenie udziału FR w globalnym rynku energii i przewiduje wzrost rosyjskich inwestycji za granicą. Ambitne założenia strategii wymagają wielkich nakładów, a ich realizacja wydaje się obecnie mało prawdopodobna. Ogłoszenie Strategii w dobie kryzysu (dokument został wstępnie przyjęty w sierpniu br. [2010]) ma zatem znaczenie propagandowe przedstawia Rosję jako globalnego gracza, odpornego na chwilowe wahania koniunktury. Dokument zastąpił Strategię energetyczną FR do 2020 r., przyjętą w 2003 r. Strategia zakłada wzrost do 2030 r. wydobycia ropy o $8,6-9,7 \%$ (do $530-550 \mathrm{mln}$ t), gazu o $33,2-41,5 \%$ (do $880-940 \mathrm{mld}$ $\mathrm{m} 3$ ), a produkcji energii elektrycznej o $17 \%$ (do 1,8-2,2 bln kWh). Będzie to wymagać inwestycji rzędu 1,8-2,1 bln USD. Jednocześnie, w ciągu najbliższych dwudziestu lat udział kompleksu paliwowo-energetycznego w rosyjskim PKB ma się zmniejszyć 1,7 raza, a udział eksportu surowców energetycznych w PKB - ponad 3 razy. Strategia zakłada również zwiększenie rosyjskich inwestycji w sektorze energetycznym za granicą, w tym zakup udziałów w zagranicznych koncernach energetycznych. Jak się wydaje, nakreślone w dokumencie cele będzie można zrealizować tylko w przypadku rzeczywistej restrukturyzacji kompleksu paliwowo-energetycznego i ze znacznym udziałem inwestorów zagranicznych, co oznaczałoby gruntowną zmianę dotychczasowej polityki Rosji. Na razie brakuje przesłanek wskazujących, że można takiej zmiany oczekiwać. Rząd zatwierdził Strategię energetyczna Federacji Rosyjskiej do 2030 r., GÓR, „Tydzień na Wschodzie. Biuletyn analityczny OSW. Rosja, Kaukaz, Azja Centralna", 2 XII 2009, nr 41, subskrypcja OSW (www.osw.waw.pl).

${ }^{83}$ A. K u p i c h, op. cit. Szerzej na temat S. Karaganova zob.: KARAGANOV, Sergey Alexandrovich, www.russiaprofile.org (dostęp 18.09.2010); http://karaganov.ru/en (dostęp 18.09.2010).

${ }^{84}$ A. Ku pi c h, op. cit. Szerzej: Geopolityka rurociagów. Wspótzależność energetyczna a stosunki międzynarodowe na obszarze postsowieckim, red. E. Wyciszkiewicz, Warszawa 2008. 